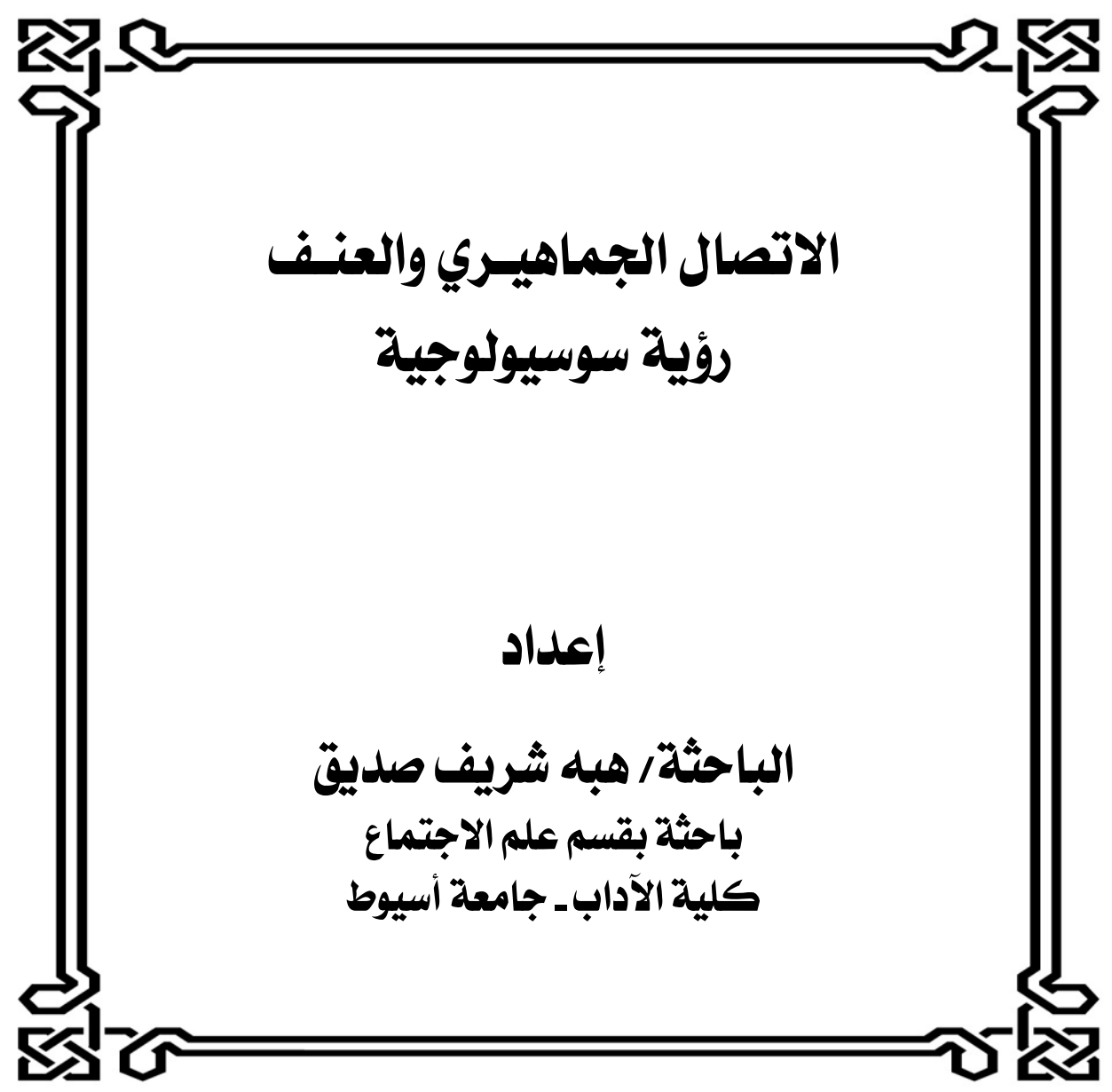


تعد منهجية الاراسـة رسما توضيحيا لخط سبر البحث بدعاً من تبلور الفكرة

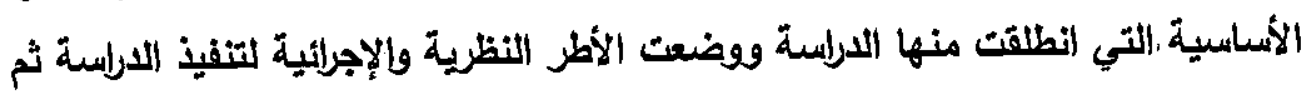
الأسباليب التفسيزية للخروج بالنتائج المرجوة التي تضع الفصل النهائي إعلانتاً منها بالانتهانء من المعل البحثي وتقديمه في شكله التهائي المتكامل بين أيلي القراء من المتخصصين والمهنمين بالعلم. ويناء على ذلك تعرض الباحثة في هذا الفصل النقاط الآتية بالعرض والتحيل

أولاُ - إثكالية الأراسة

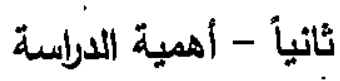

تالثأ - أهدافـ الدابسة

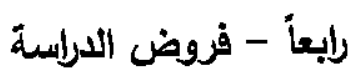

خامساً - مفاهيم الادراسة

سادساً - التوجه النظلي اللاربسة هاسية

سابعاً - مناهج الدرإسة

ثامناً - أداة جمع البيانات

تاسعان - مجتمع وعينة الارلسة

عاثراً - تحليل وبتفير البيانات

الحادي عشر- فروض الدراسة ونتائجها 


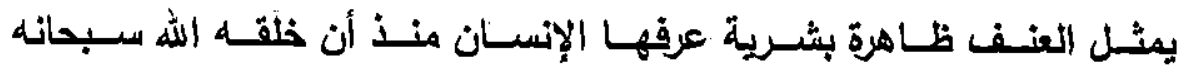
وتعـالمى ليعمر الأرض وذلـك عندما قتل قابيـل أخـاه هابيـل إرضـاء لشـهوتهاه وطاعـة

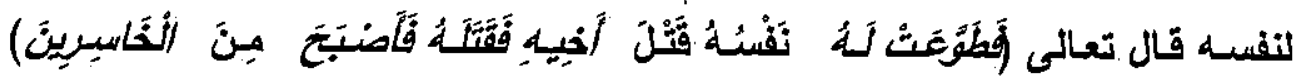

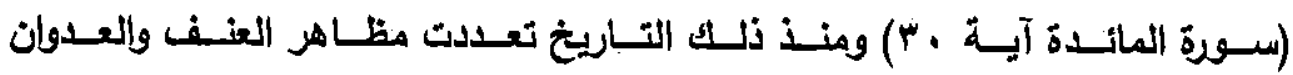

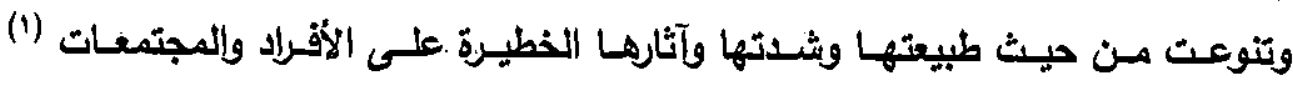

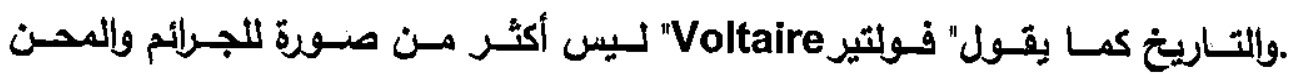

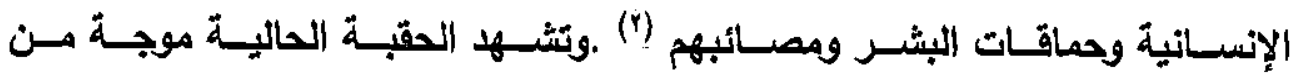
العنف والانفجار السلوكي العنيف في سائر أنحاء العلام.

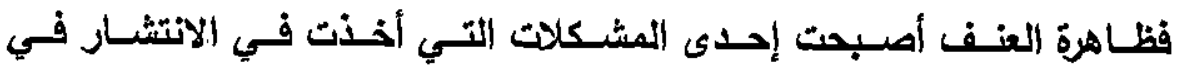

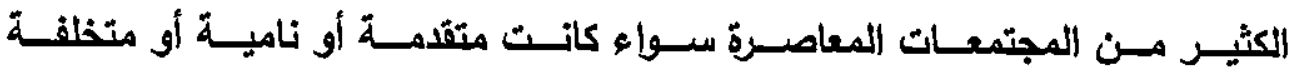

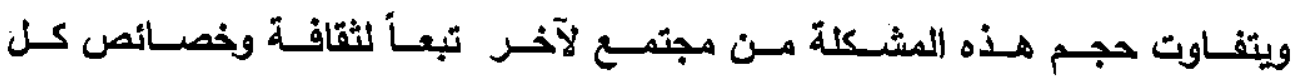

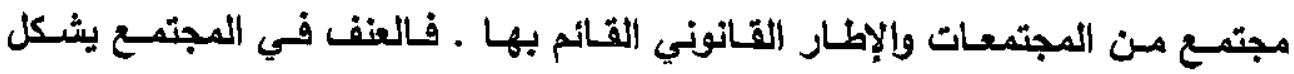
انتهاكا لحقوق الإنسان وهذا واقع مؤرق في مجتمعاتنا (r) . كمـا تشـير الإحصـائيات الجنائيـة في كثيـر مسن دول العـالم إلـى أن العنـف فئف قـد انتثـر عـى نطساق وإســع وازدادت حلتـهله حتـى أصسبح يمثـل مشـكلة اجتماعيـة

أساسية في المجتمعات المعاصرة (\&)

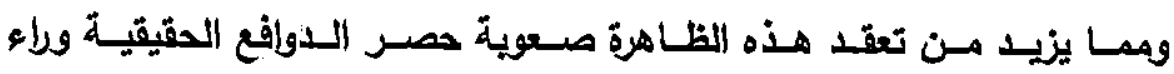

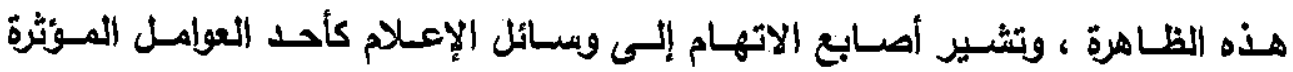

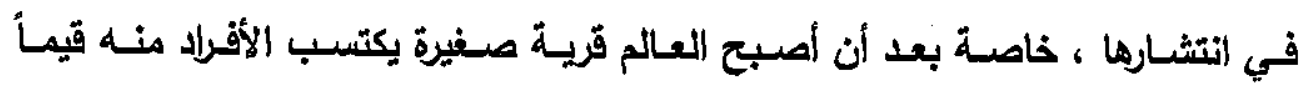


الأتصال الجماهيري والعنف روية سوسيولوجية

هبه شريف صديق

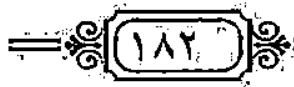

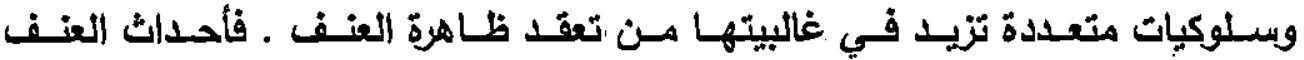

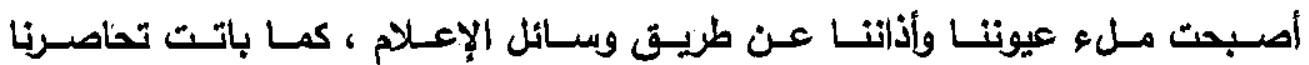
بآثارهـا ونتائجها في كل مكـان بـل في كل مظـلهر مياتنـا السياسـية والاتتصـادية

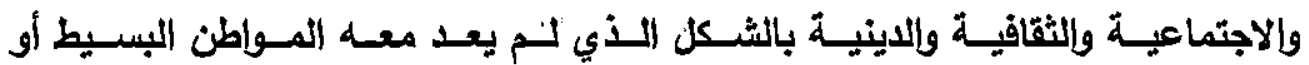

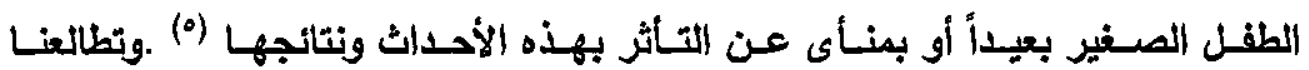

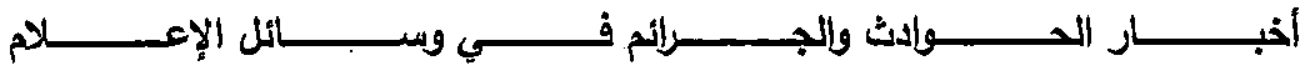

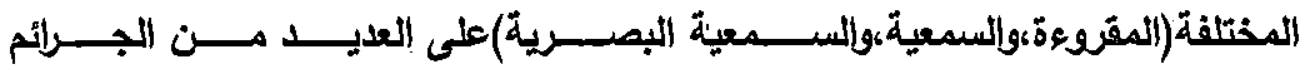

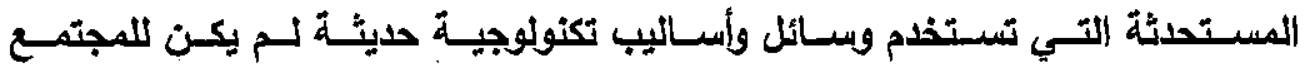
(المصري عهt بها (1) أقد أصسبحت وبسائل الإعـلام هـي الأولمى التـي تمــنا بكثيـر مسن الخبـرات أو نـتعلم منهــا كثيـراً مـن مظـاهر الحيـاة مـن حولتـا ، ومـع تقــم وسـائل الإعـلام

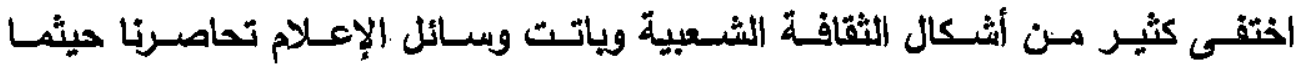

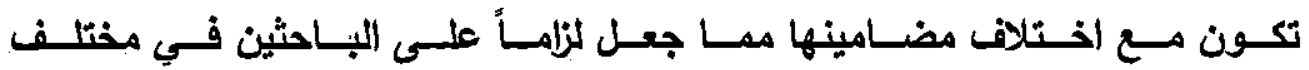
المجـالاتت الاجتماعيـة وإلنفسية والإعلاميـة أن يبحثــو فـي تـأثير وسـائل الإعـلام الجما هيرية على التاس اهن وتعـرض لنـا وبسـائل الإعـلام على ندـو شـبه يـومي بالعديـ من الأحسداث

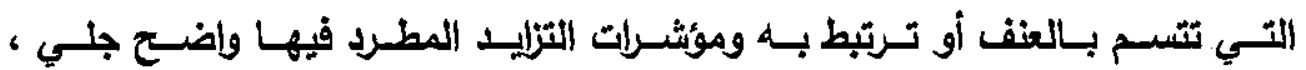
أيضاً فإن جرعات العنف تتسم بالمبالغة والقسوة في كثير من الأحيان (r) .

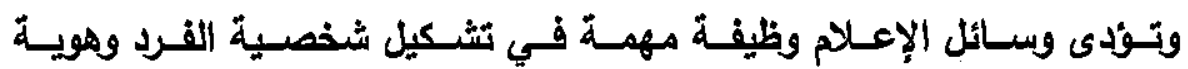
المجتمـع حيـث أثبتـت العديد مـن الإراسـات الإعلاميـة قدرة هذه الوبـائل في تغيـر 
الأتصال الجماهيري والعفف روية سوسيولوجية

هبه شبريف صديق

$=8$

)

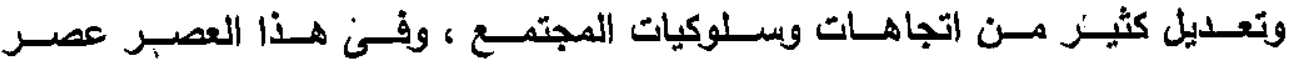
المعلومـات والإعـلام أصسبحت وسـائل الإعـلام أداة رئيسـية ووسـيلة مهمـة للتـأثير

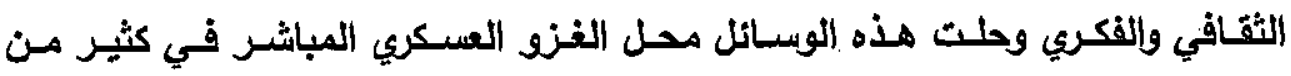

المجالات وغدت بذلك الموسيلة الأكثر نجاحاً للغزو القكري الثقافي (") والحـديث عـن دور وسـائل الإعـلام وتـأثيره عنى إلأفــاد والمجتمـع يجعنـا.

أمام فرضيتين أساسيتين هما :

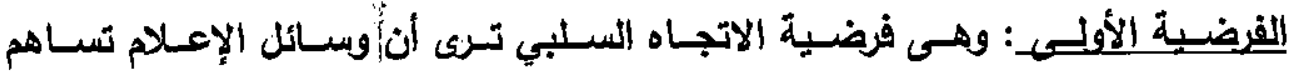
فـي انتشـار العنف وبثقافته ويذلك مـن خـلال المضـامين التـي تضـعها في متنـاول

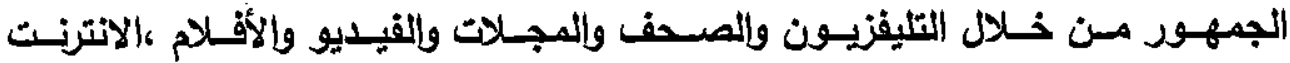
... إلــخ فـالإعلام بعطى صـورة مجسـدة للعنـف، ويختلف تـأثنير مشـاهد العنـف

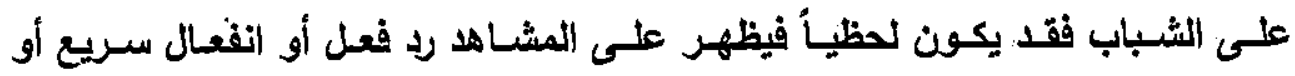

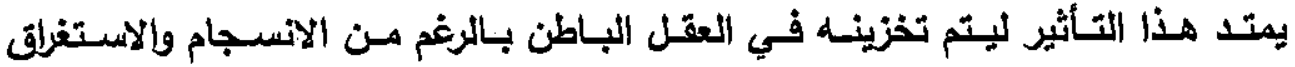

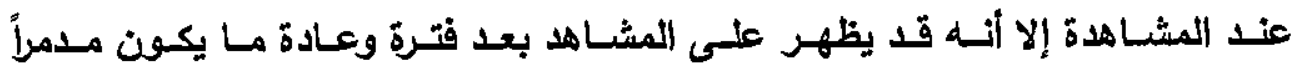

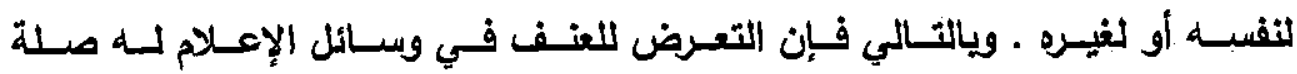

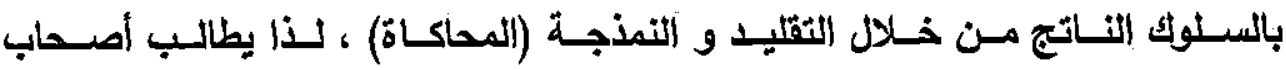
هذه الفرضية برقابة مشددة على المحتويات الإعلامية العنيفة . أمـا القرضـية الثانيـة : وهـى فرضـية الاتجـاه النشـط أو المشسارك فيتعـى تصـورها

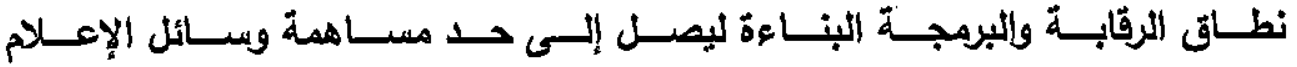
ومشـاركتها المباثــرة والصــريحة فـي التصــدي لمشـكلة العنـف وذلـك مسن خـلال

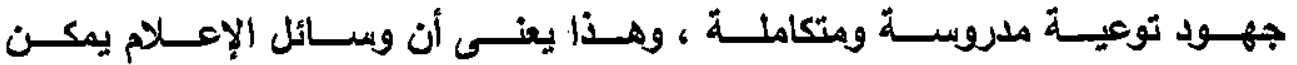


اسـتغلالها عـن طريـق الممـلات الإعلاميـة التـي تسـعى إلـى اسـتبدال المعلومـات

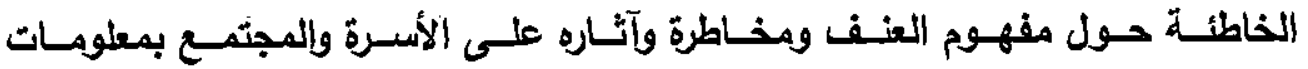
حقيقيـة ودقيةـة وذلـلك باسـتخدام وسـائل إعلاميـة مخصصــة لهـذه الغايـة ،ومـازال الجـل محتدماً حـول الايجابيـات والسـليات التـي تحققها ونسائل الإعـلام. مـن هنـا بدأت تتبلور مشكلة الدرابنة ويمكن صياغتها من خلال الشكل التوضيحي الأنتي : lin

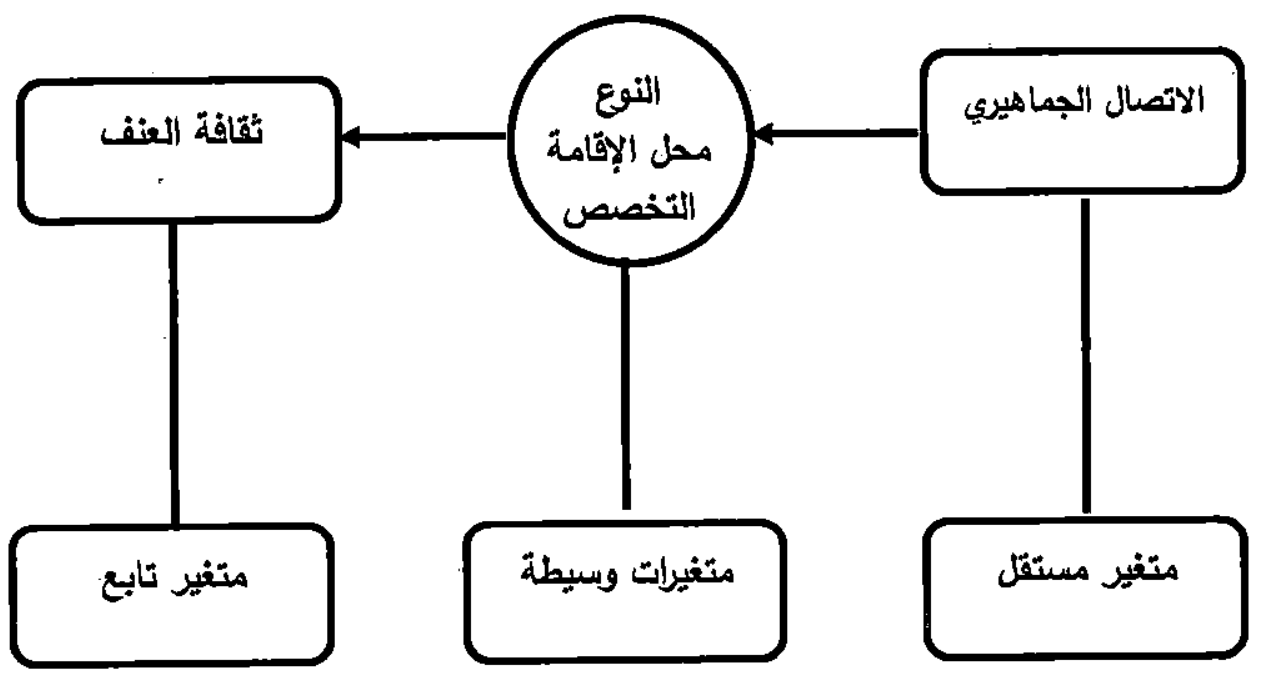

وفـى عصــنا الحـالي أصـبع العنـف المفــدم عبـر وسـائل الإعـلام خبـزاً يوميـاً للإنسـان المعاصـر يصـعب تجنبـه أو رفضـه، فـالعنف جـزيه ضـروري ومهـم

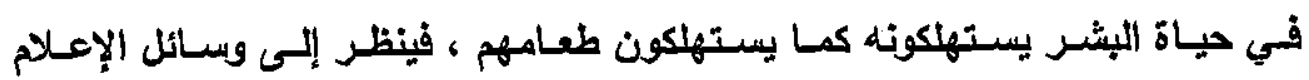

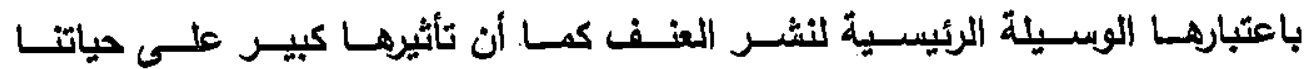
وتصرفاتنا . 


\section{$=$ प110}

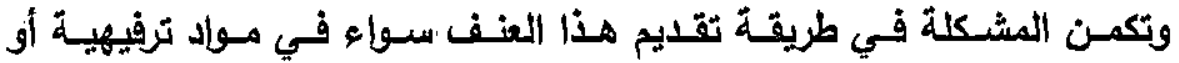

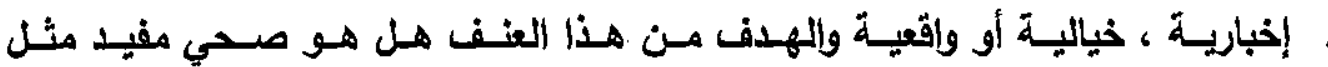
التحــير مـن تكرار حـدوث شـئ ضـار مـرة أخـرى أو بالإثــارة إلـى وجـود خطـأ أو

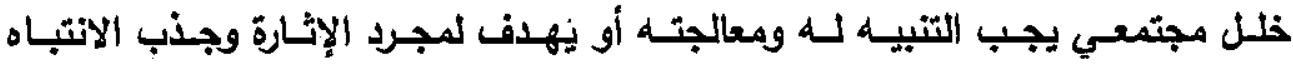

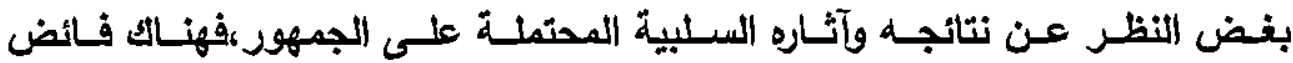

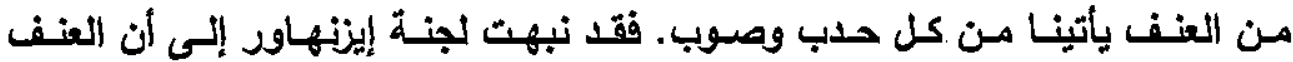
الإعلامــي عامـل مُسـاهم يسـاعد إلـى حـ كبيز على نمـو ثقافـة العنـف بـين شـرائح |لمجنمع.

ونظـراً لتنـامي أنمـاط سـوكية عنيفـة في المجتمـع المصـري وإنعكاسـها في

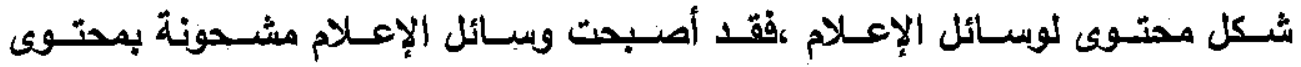

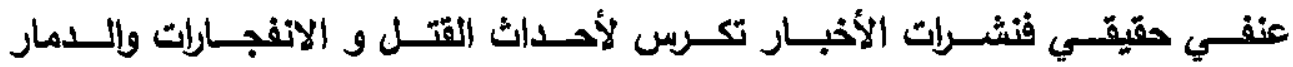

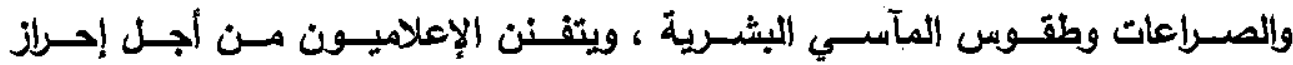

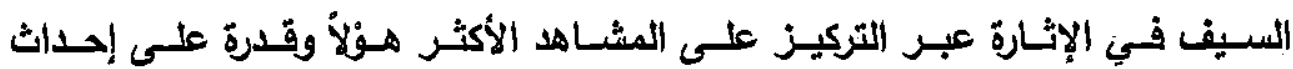

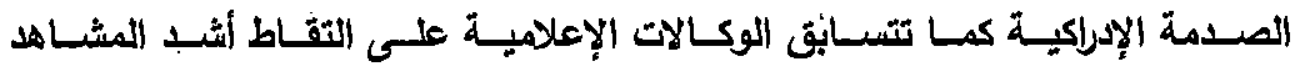

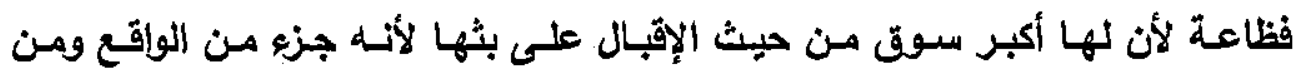

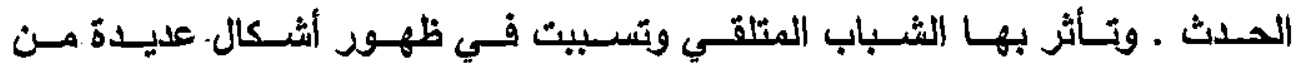

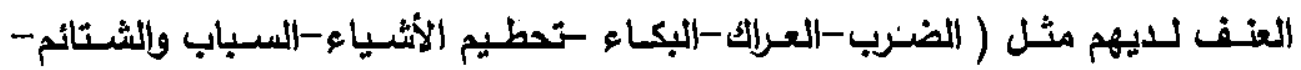

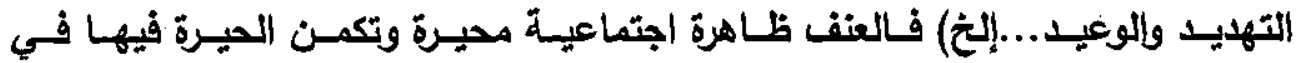
الـرفض الاجتمـاعي لهـا مـن جانـب الأفزاد والجماعـات الاجتماعيـة ومـن المــهش 


\section{$=8$}

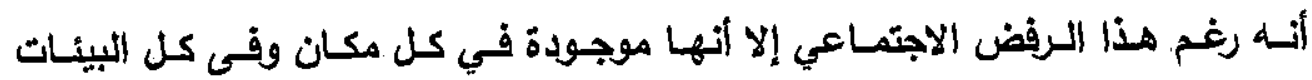
على حد سواء وتأخذ تلك الظاهرة أشكالاً وصوراً مختلفة . وعليـه يمكن القـول بـأن وبسائل الإعـلام وإن كانـت تمثنل سـلاحاً ذو هـدين (الجانب الإيجـابي والجانـب السـلبي) فإن الماقـع الاجتمـاعي إضـافة إلى مالهـا مسن

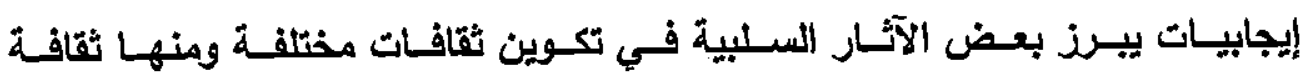

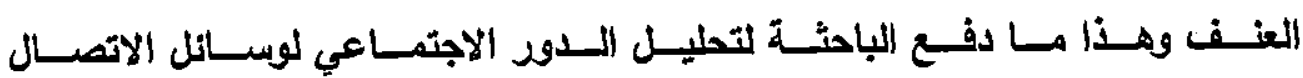
الجماهيري وأثرها في تكون ثنقافة العنف . ثانياً: : أهمبة الاربسية

تتبع أهمية الارلسة من خلال أهمية العناصر التي تتناولها وهى : ا- فــي ظـل التـورة التكنولوجيـة والمعلوماتيـة والثـبكات العالميـة يلعـب الإعـلام

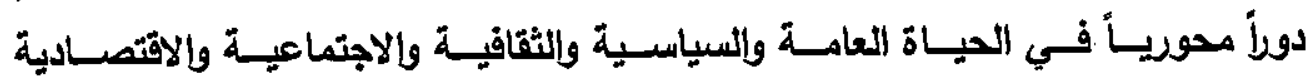
والبعض ذهب إلى أن التغير الثقافي ما هو إلا ثمرة من ثمرات وسائل الإعلام .

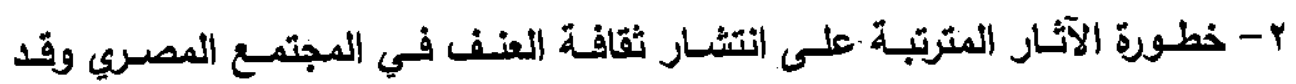
وجهت أصابع الاتهام إلمى وبائل الإعلام .

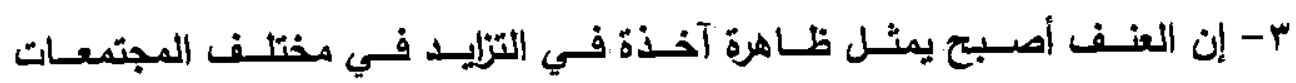

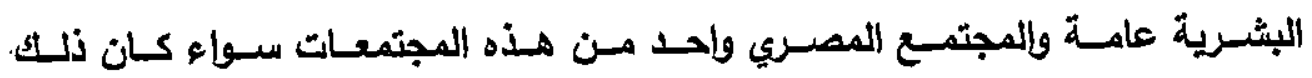

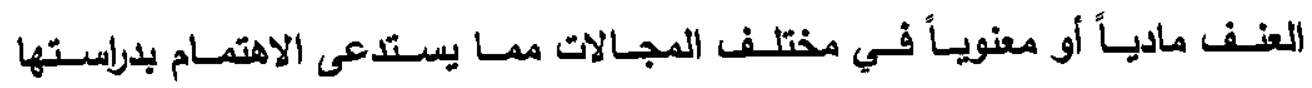


الأتصال الجماهيري والعنف روية.سوسيولوجية

هبه شريف صليق

$=0$

$\omega$

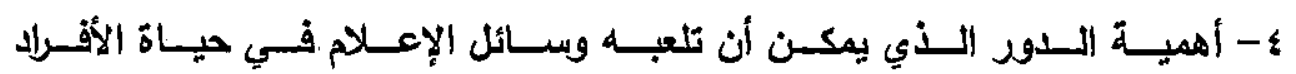

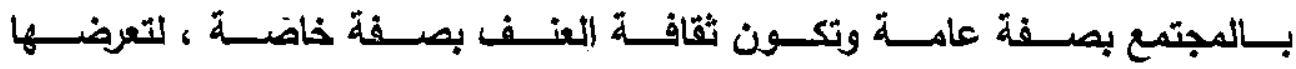
لموضوعات العنف وعزضها لصور العنف اليومية .

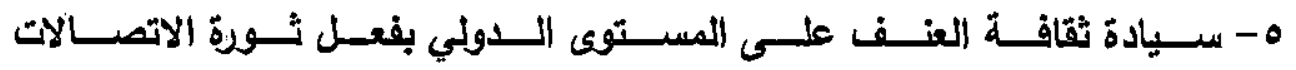
والمعلوماتيـة والتتي لا يمكن بـأي حسال الحيلولـة دون وصـولها لكل مـواطن مصـري

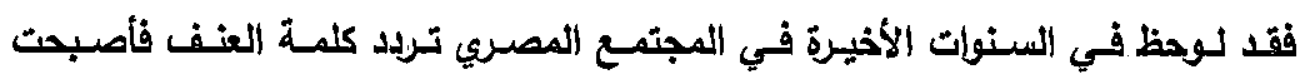
من أكثر الكلماث تداولاً في إعلامنا وفى الأحاديث اليومية العادية . . . .

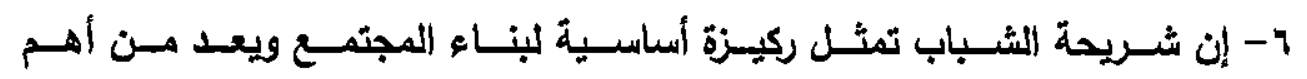

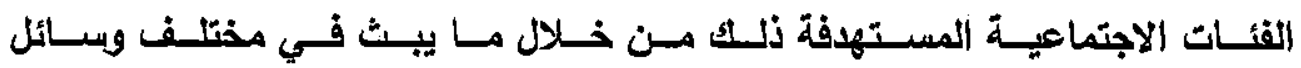
الاتصال الجماهيري من مواد إعلامية .

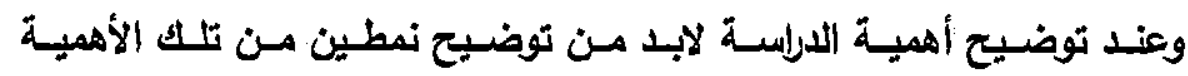

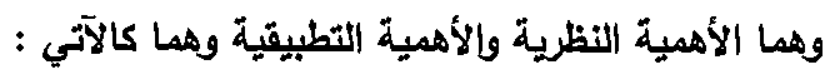

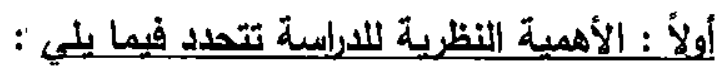

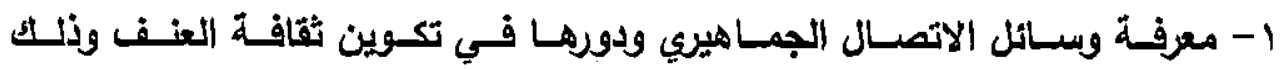

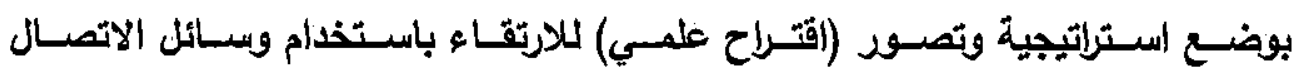
الجماهيري بشكل أفضل لا ينعكس سلباً على أقراد المجتمع .

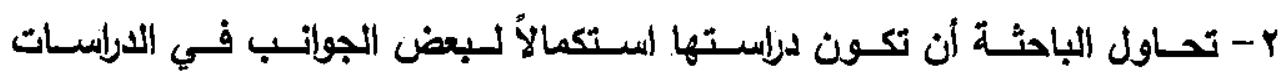
اللسنابقة والوصول إلمى مجموعة من النتائج والتوصيات يمكن الاستقادة منها .

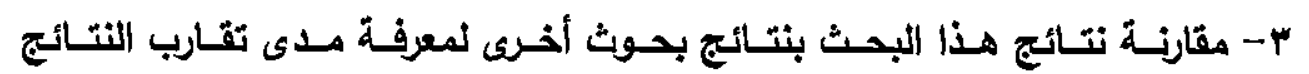
الحالية هيع النتائج السابقة . 
الأتصال الجماهيري والعنف رؤية سوسيولوجية

هبه شريف صديق

$=0 \mathrm{O}$

ثانياً : الأهمية التطبيقة للإسية فتتحدد فيما يلى :

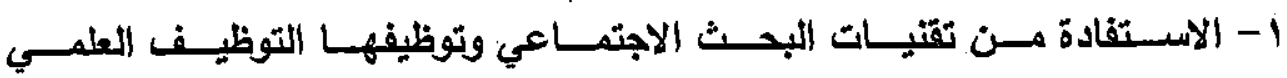

المناسـب مسن خـلال التعـرف عنى الـدور الـذي يمكن أن تلعبسه وسـائل الاتصـال الجمـاهيري في تكسوين ثقافـة العنـف لـدى الشــباب عينـة الاراســة والاســفادة مـن نتائج البحث في التطبيق المعمي .

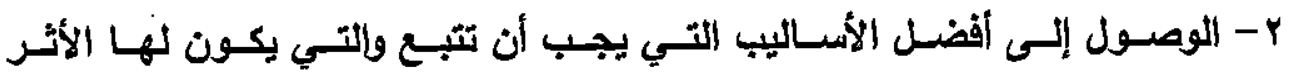

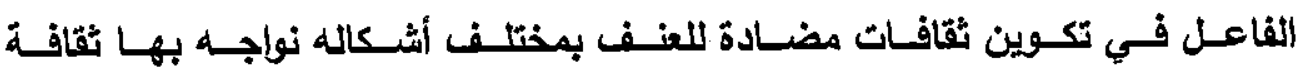
العنف السائدة جنباً إلى جنب .

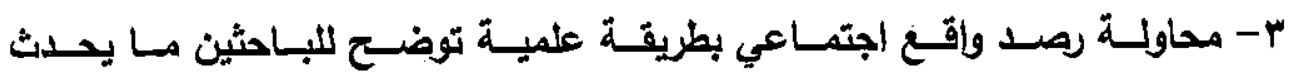
ومحاولـة الاســفادة منهــا بطريقـة علميـة للمســاعدة فـي الوصسول إلـى مجتمــع أفض

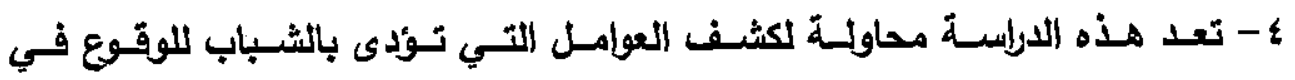
برائن العنف ومدى ما يمثله زلك من إهدار لمكانة الفرد في المجتمع .

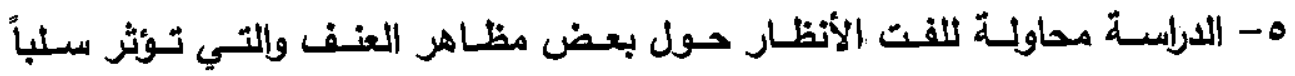
على خطط التثمية في كافة المجالات الاجتماعية والسياسية .

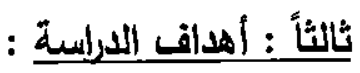

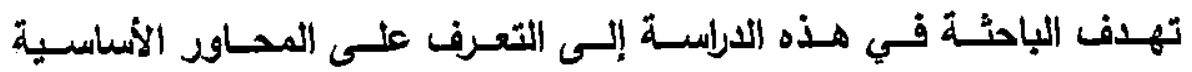
الثالية

ا-التعــرف علــ مســتويات التعـرض لوبــائل الاتصــال الجمــاهيري التقليديــة

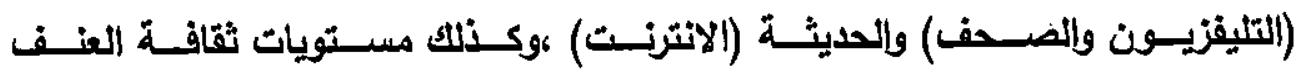




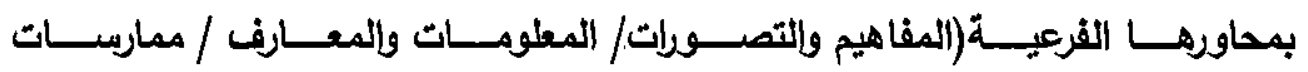
المنف) لاى عينة الاراسة من الثباب الجامعي. Y- الكشـف عـن مـدى تبـاين تـأثير التعـرض لوسـائل الاتصـال الجمـاهيري فـي

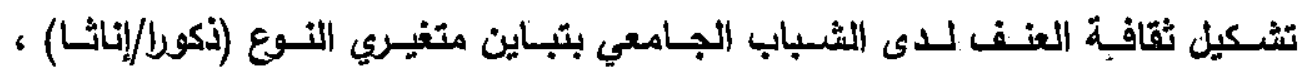
محل الإقامة (ريفا/حضرا) ،والتقاعل بينهم

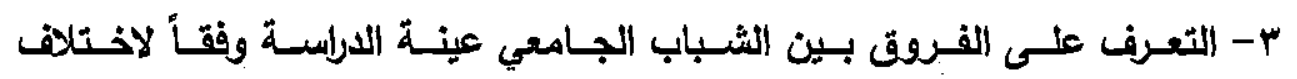

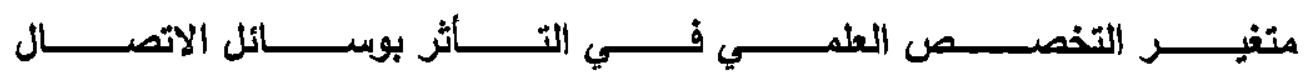
الجماهيري(الانترنت/التليفزيون/الصحف)

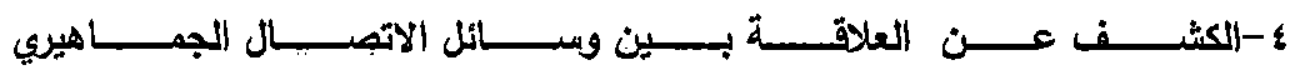

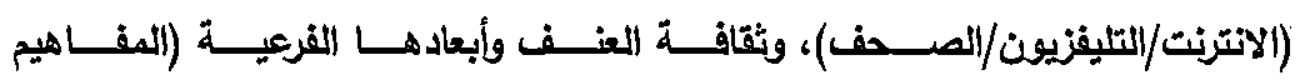
والتصــورات والمعلومسات والمعـارف وممارسسات العنـف) لـدى عينــة الادراســة مـن الشباب الجامعي

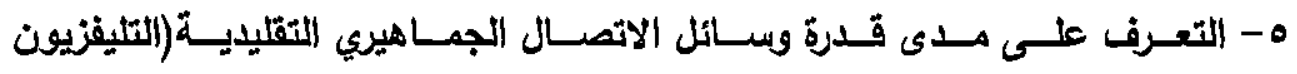

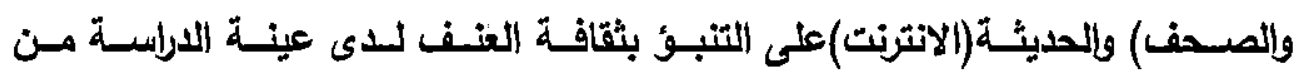
الثباب الجامعي

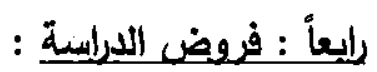

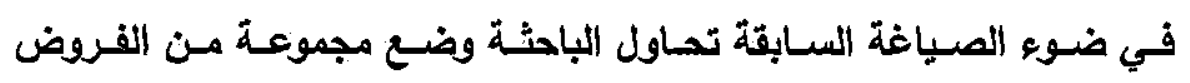

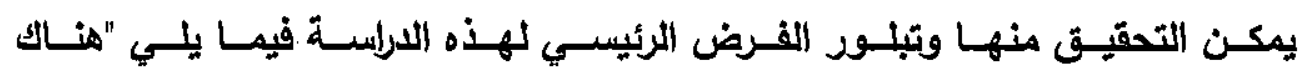

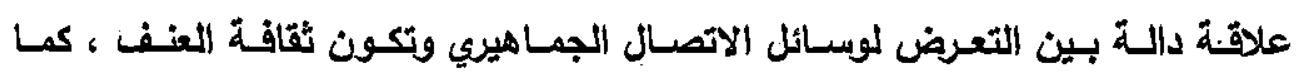


الأتصال الجماهيري والعنف روية سوسيونوجية

هبه شريف صديق

$=19.90$

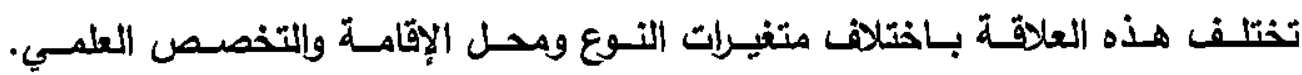
و ينبثق منه عدة فروض فرعية هي :

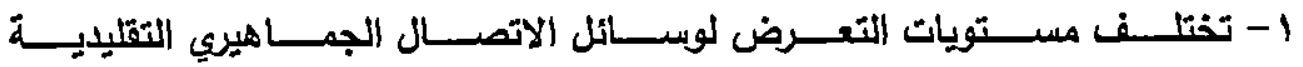

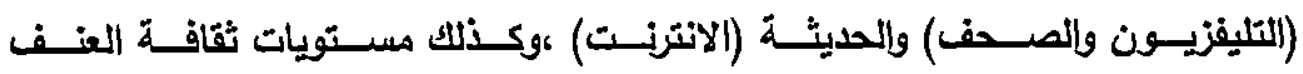

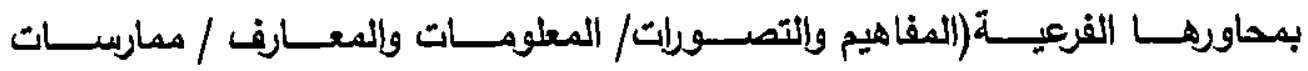
العنف) للى عينة الاراسة من الشباب الجامعي. Y - يتبـاين تـأثير التعـرض لوسـائل الاتصـال الجمـاهيري فـي تشـكيل ثقافـة العنـف

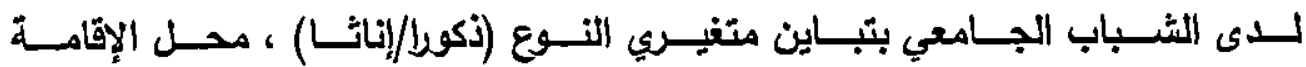
(ريفا/حضرן) ،والتقاعل بينهم?

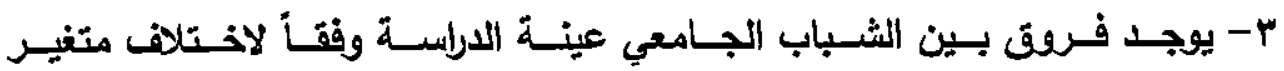

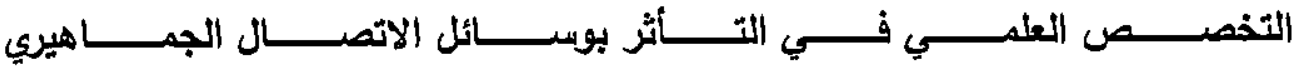
(الانترنت/التليقزيون/الصحف)

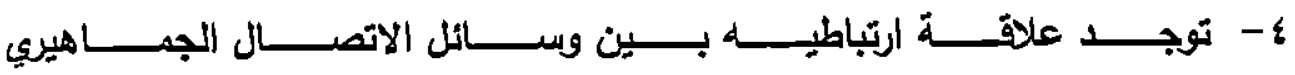

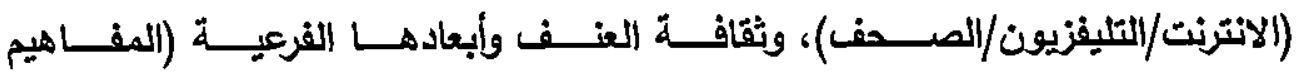

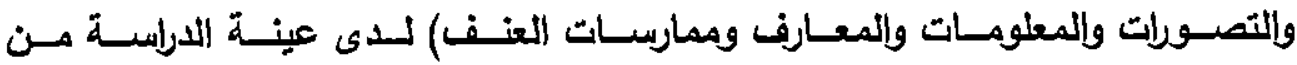
الشباب الجامعي ه- مــدى قـــرة وســائل الاتصــال الجمــاهيري التقليديــة(التليفزيون والصــحف)

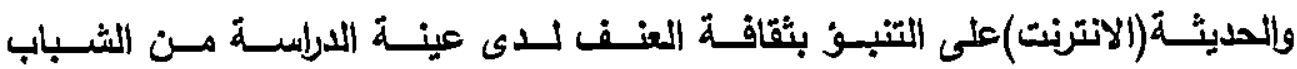
(ل) 


\section{خامساً: المفاهيم اللإحرائية للدراسة}

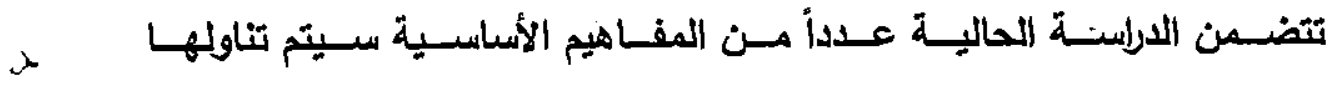

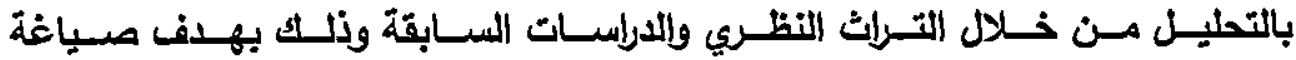

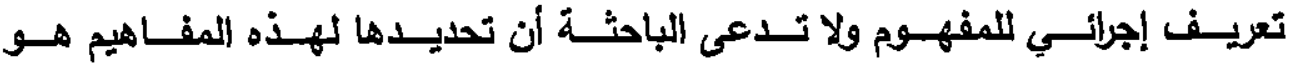

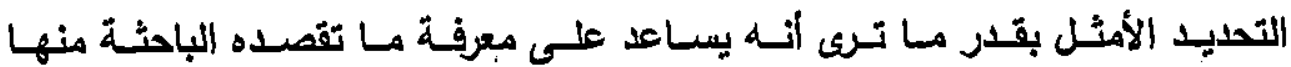
دون لبس أو تاويل. التعريف الإجرائي للاتصال الجماهيري : هـو العمليـة التـي تـنم باســتخدام وسـائل الإعـلام الجماهيريسة كـالتليفزيون والصــف والانترنـت حيـث يـتم مـن خلالهـا توصـيل المريـائل إلـى جمهـور عـريض متبـاين الاتجاهـات والمسـتويات حيـث تنتقـل المعلومسات والأفهـار بـين التباس دون

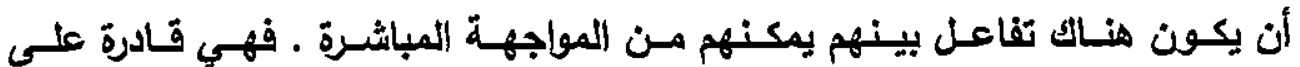

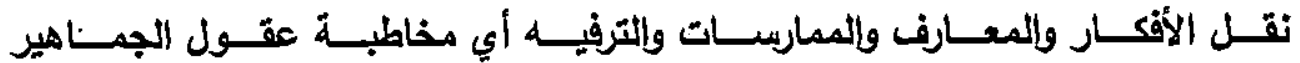

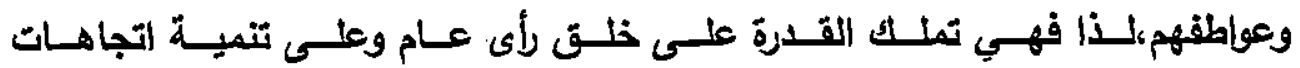
وأنماط جديدة من السلورك وإلممارسات. التعريف الإجرائي لثقافة المنف :

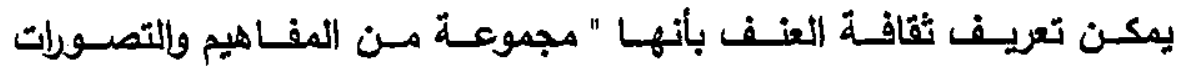
والمعسارف حول العنـف تـنكس في مماربـات عنيفة، ويصـبح مثّل هـذا السـلوك

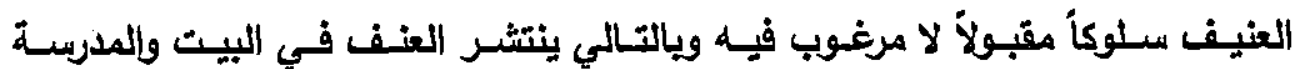

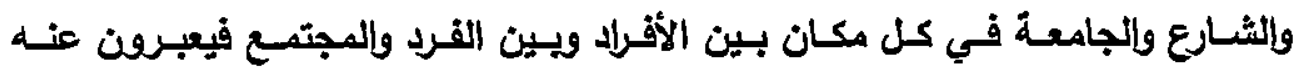

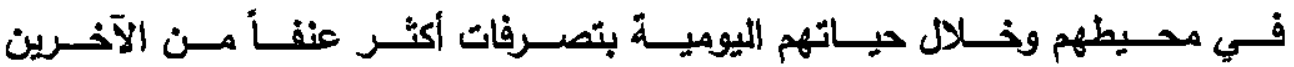




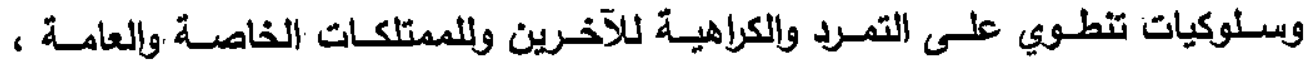

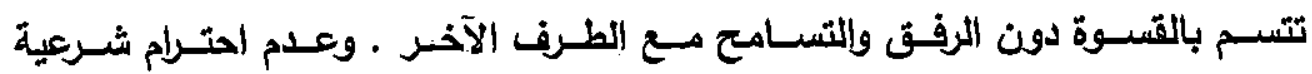

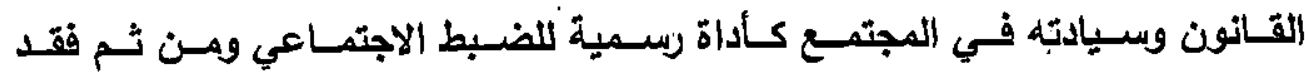
القانون هيبته في أذهان البعض واعتبر الخروج عليه سلوكاً منارياً . التعريف الإجرائي اللشباب :

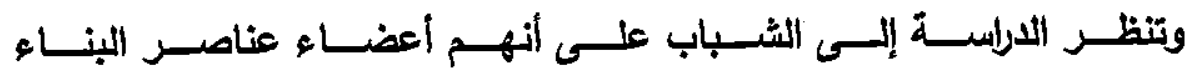

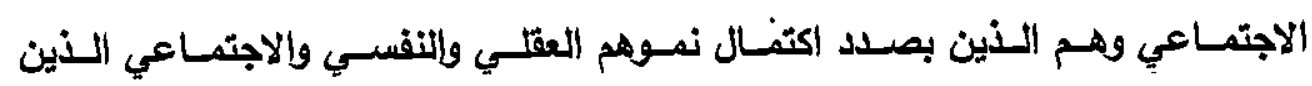

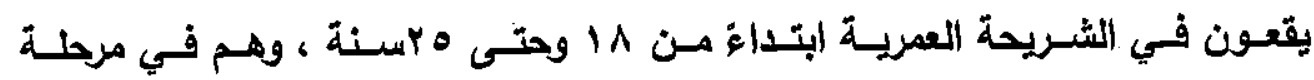

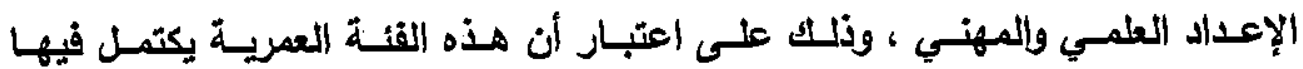

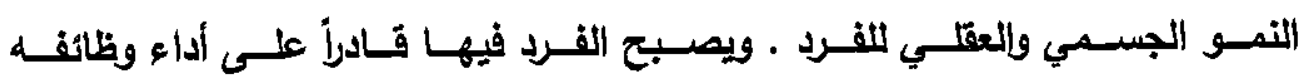

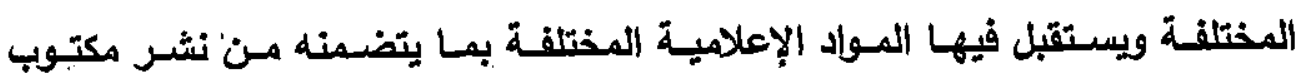
أو بـث مسـموع أو إرسبـال مسـموع ومزئي أو غيـر ذلتك ،بالتـالي يكـون لايـه القدرة على ترجمة ما يتأثر بة إلى مجموعة من التصرفات وإلسلوكيات .

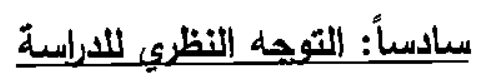

يعتبـر وجـود نمـوذج نظـري أمسراً هامــأ فـي المبحـث العلمـي لكـي يقـود

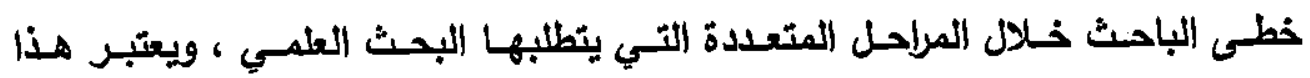
مـن أهـم أهداف النظريـة إذ أنها توجـه الباحث إلى طبيعـة اللبيانـات التي يحتاجها

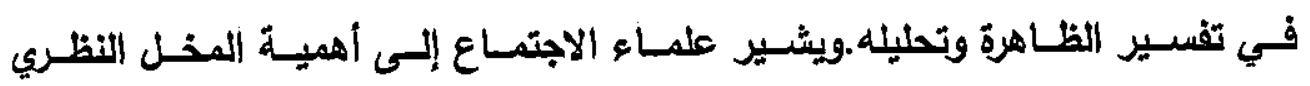
للارلسـة السوسـيولوجية حيث إن هـا المـدخل يعـد بمثابـة الـدليل أو المنهـاج الـذي

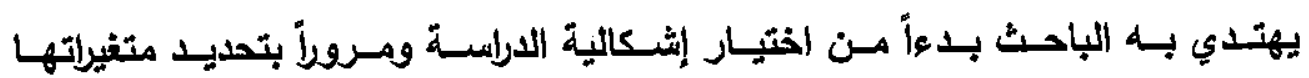


الأتصال الجماهيري والعنف روية سوسيولوجية

هبه شريف صديق

$=0$

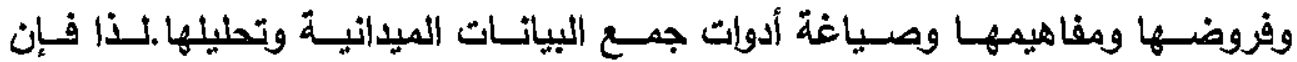
أي درإنة في العلم الاجتماعي لابد أن يكون لها إطار نظري.

دارت تفسيرات سوسيولوجية حول الإعلام ودوره فى المجتمع فقد استطاع "

أنتوني جلنجزAnthony Giddens"أن يصوغ مثكنة البحث في موضوع المخاطر وأن يحدد العلاقة الوثيقة بين العولمة والإعلام وتحول المجتمع الانسانى هن الأمن النسبي إلى مجتمع المخاطر.ولا بعنى مجتمع المخاطر بذاته.اته مجتمع تزيل فيه معدلات الخطر بقر ما يعنى أنه مجتمع منظم لمواجهة المخاطر لأنه مشغول بالمستقبل ويالأمن بشكل متزليا وهو الأي ولد فكرة الخطر . ومجتمع المخاطر هو نظرية اجتماعية تصف إنتاج وإدارة المخاطر في المجتمع الحديث ، فقد أبرز" أنتوني جلنزئ Anthony Giddens" قوة العلاقة بين العولمة والمخاطر ويقول في كتابة (علم الاجتماع ) تؤدى المعولمة إلى نتائج بعيدة المدى وتترك آثارها على جواتب الحياة الاجتماعية جميعها باعتبارها عملية مفتوحة متناقضة العناصر بسفز عن مخرجات يصعب التكهن بها أو السيطرة عليها، فكثيراً من التغييرات الناجمة عن العولمة تطرح علينا أشكالا جديدة من الخطر تختلف اختلافا بيناً عما ألفناه في العصور السابقة.

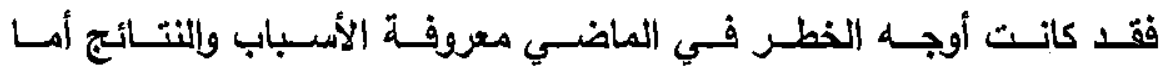

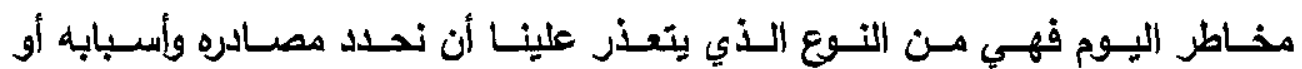

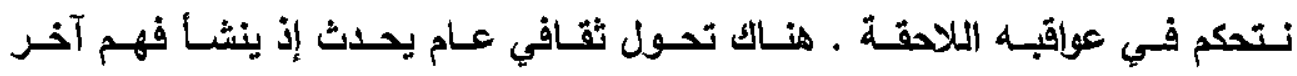

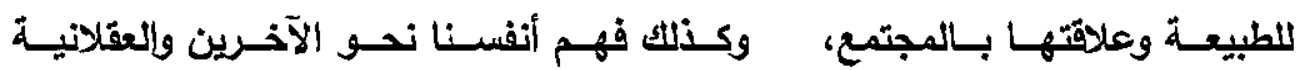

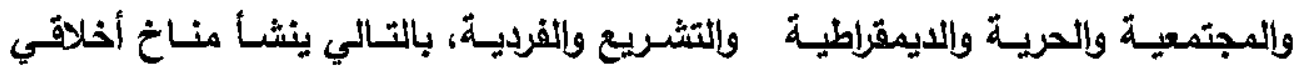
وتثقافي جديلد تلعب فيه وسـائل الإعلام و القيم الثقاقية التي تختلف مـن بلد إلى 
الأتصال الجماهيري والعنف روية سوسيولوجية $=\frac{9}{19 \varepsilon}$

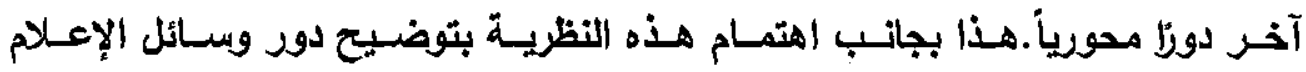
الجماهيريــة فــي الكشـف عـن المخــاطر ووصسف ضــروب المصسالح اللسياسـية والعلمية المتنافسة والخاصة بكيفية إدارتها . ألمان

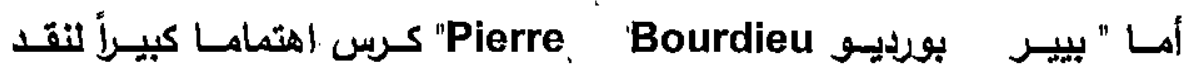
الــدور الـذي تلعبـه وسـائل الإعـلام وسـن نقـداً حـاداً عنى فسـاده.ويرى أن التحـول

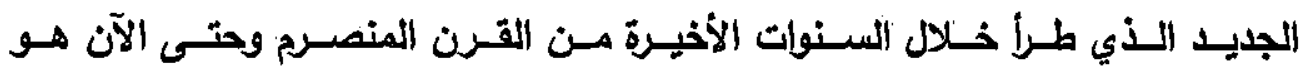

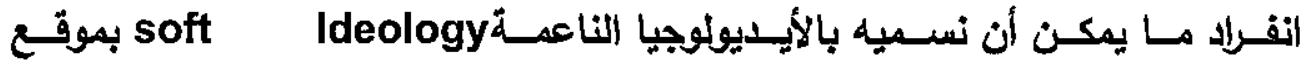

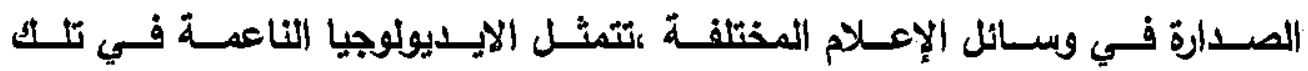
الجرعـات اليوميـة بـل اللحظيـة التي تبثها وسـائل الإعلام الحليثة وكـلاك الوسـائط المتعـددة وإنتشـار شـبكة الانترنست علـى المسـتوى العـالمي ، كـل هـذه الجرعـات

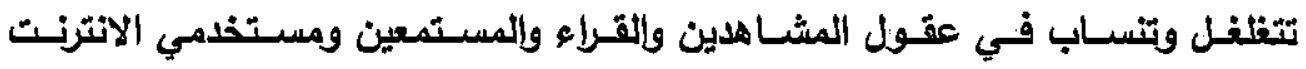
فالتخدم " بييز بورديو Pierre Bourdieu".... أطروحات وهى كالتالمي: الأولىى: تقـول بـأن العنـف هـو نتيجـة طبيعـة لنظريـة الحاجسات فالضـرب والشـغب تظهـر حتميـة لعـدم إثـباع حاجـات الإنسـان منهـا اللسـكن ،الانفجسار الـديموغرافحى

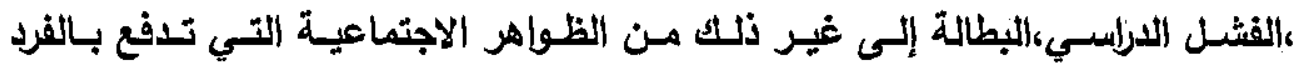
إلمى ممارسة العنف.

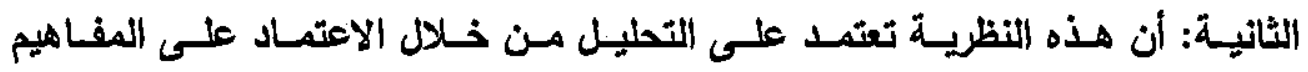

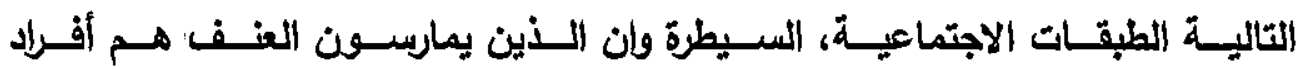
ضائعون داخل النسث المسيطر عليهم وهو ما يسمى بالعنف الرمزي. الثالثة: المنف الفيزيقي الثي يسمح للأفراد للوصول إلى السلم الاجتماعي. 
مـن خـلال هـذه الأطروحـات يوجـد عـدة عوأمـل وميكانيزيــات تـتحكم فـي طـاهرة

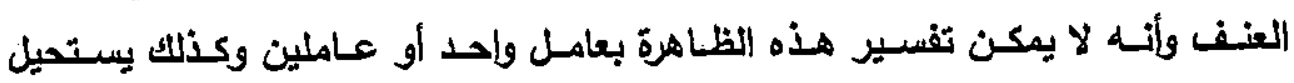
|التعميم |

وتنطلق الباحثـة في دراســها لموضـوع الاتصـال الجمـاهيري وتكـون ثقافـة العنـف مـن خـلال نظريـة الغريس الثفـافي cultivation theory ميث إن الإعـلاتم يمثَل همـزة الوصـل بـين المجتمـع المحلى والعـالم الخـارجي ويشـكل دوراً في تغيـر السـلوك والقيم .تـربط هذه التظريسة بـين كثافـة التعرض لوبسائل الإعـلام

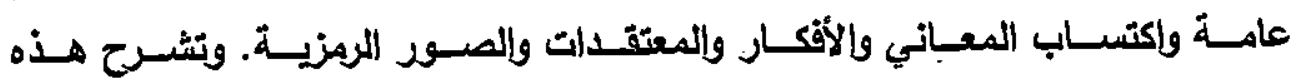

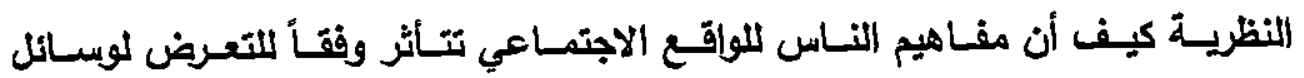
الإعلام،كما تهتم بالتأثير التراكمي طويل المدى لوبائل الإعلام عامة. تعتبر نظريسة الغرس الثقافي تصسويرا تطبيقيا للأفكار الخاصسة بعمليات بنـاء المعنسى و تشـكيل الحقـائق الاجتماعيـة و الـتـعم مسن خـلال الملاحظــة و

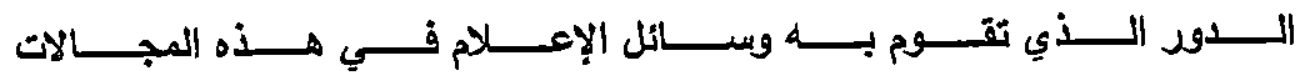

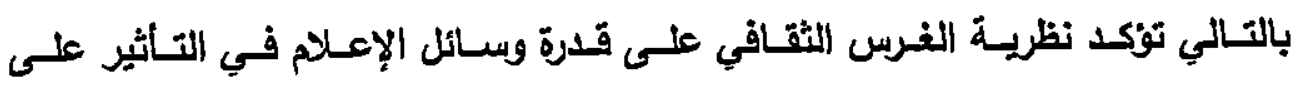

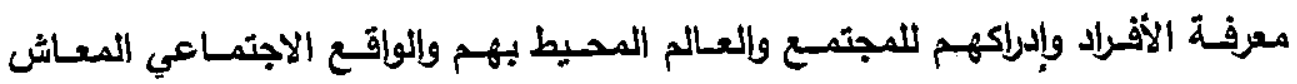

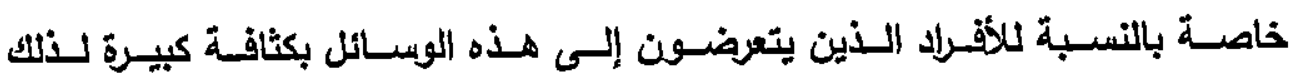

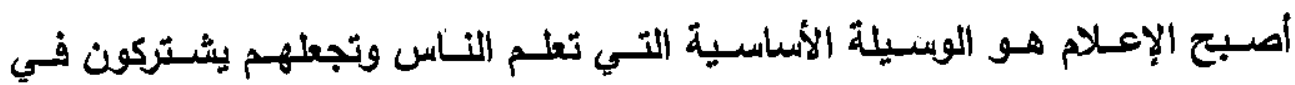
ثقافة عريضة .

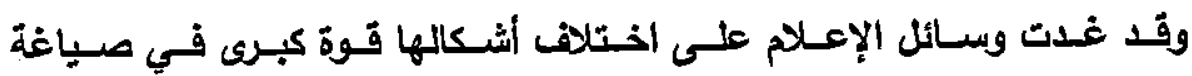

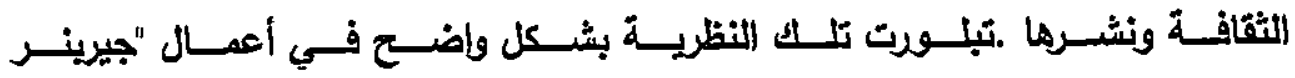




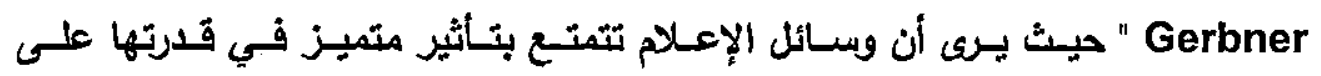
زرع الأقكار والقيم المثقافية.

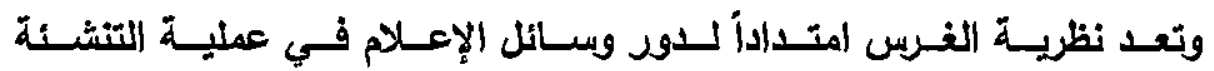

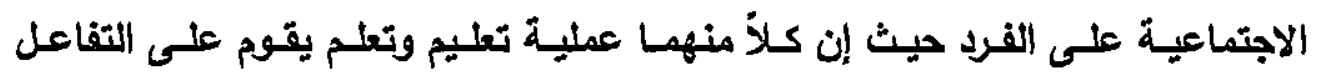

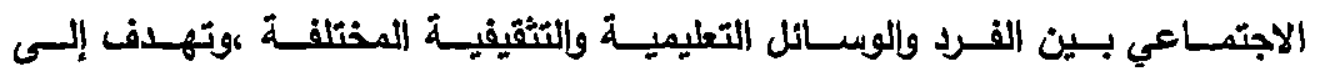
إكسـاب الفـرد اتجاهـات وسـلوكيات تتناسـب مسع دوره الاجتمـاعي تسـهل لـه عمليـة

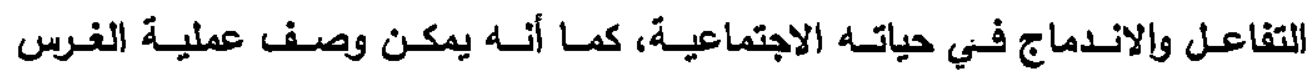
بأنهـا نـوع مـن الـتعلم العرضـي الــي ينستج عن التعـرض التراكمـي لوسـائل الإعـلام

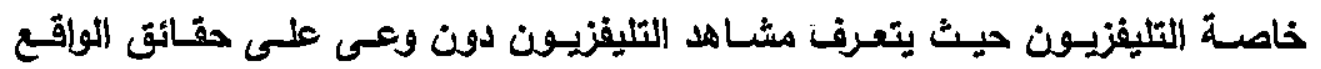

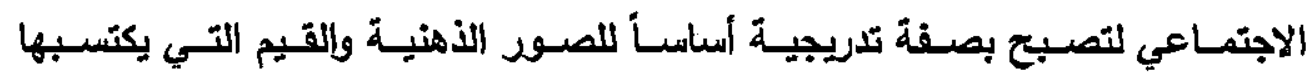
عن العـالم الحقيةي ،وعملبـة الغرس ليست عبـارة عن تـدفق موجـه مـن تـأثيرات التليفزيـون إلـى جمهـور المتلفـين ،ولكنهـا جـزيع مـن عمليـة مسـتمرة وديناميكيـة للتفاعل بين المبسائل والمبياقات. كمـا يـرى "جيرينـر Gerbner "أن وبــائل الإعـلام تســنيع أن تغـرس فـي

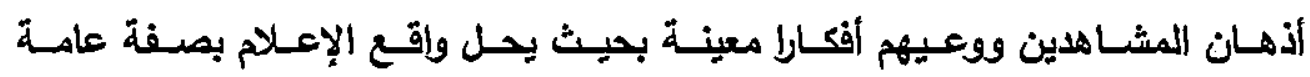

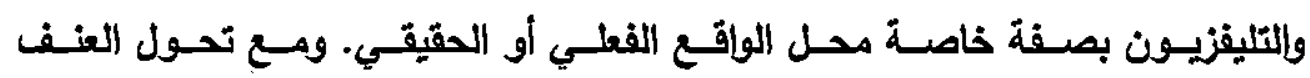

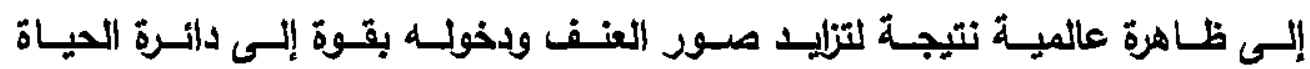

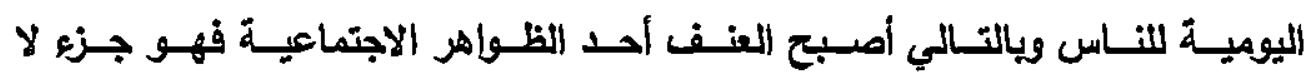
يتجـزأ مـن تفـاعلات الأفراد في حيـاتهم اليوميـة، ومــع وجـود صـورة مجسـدة للعنف

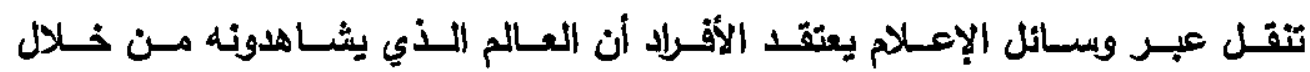


ونسـائل الإعـلام عامـة وإلتليفزيـون بصـفة خاصـة هـو صسورة مـن العـالم الــوإقعي

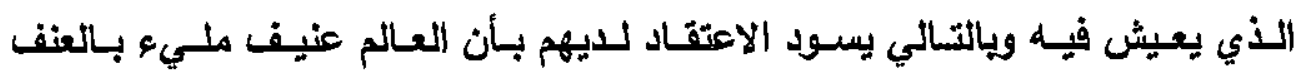
( يخلط الأقراد بين واقعهم وما يشاهدونهيه).

ويعـد انفجار ثـورة المعلومـات و انتثـار وبـائل الإعـلام أصسبح مسن السـهل معرفـة

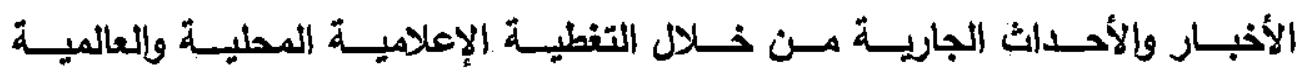

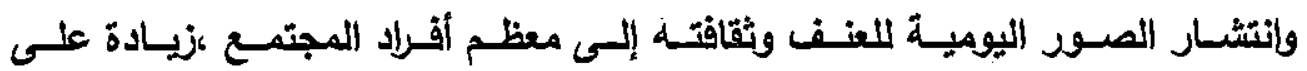

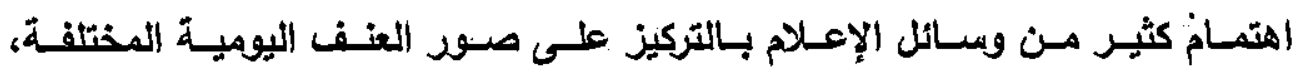
ويالـذات جانـب الإثـارة فيها والتـي يعتقـد انهـا تلفت انتبـاه وإهتـام المتـابع للإعـلام والأحسات الجاريـة، ويلاحطظ أن هنـاك تركيـزاً مسن هـذه الوبـائل عنى صـور العنـف

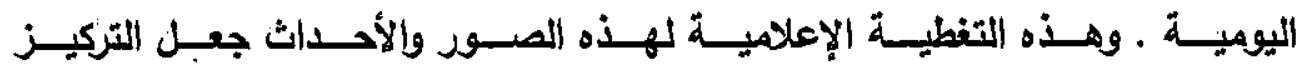

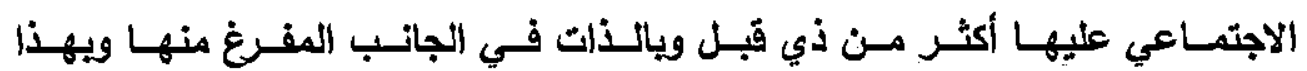
تصـبع وسـائل الإعسلام إحـدى الآليـات التـي تعـزن السـلوك العنبـف لـدى الفـرد المتلقي . وذالك ما ستدرسه الباحثية ونثبته الدرإسة.

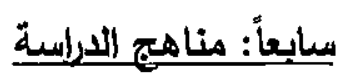

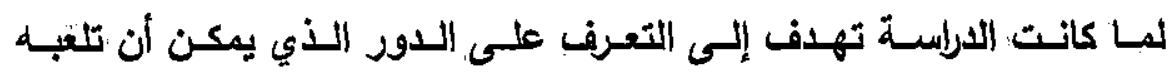

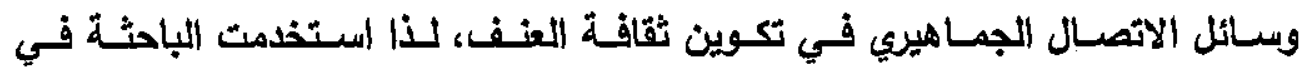
الادراسة الحالية المناهج الآتية:

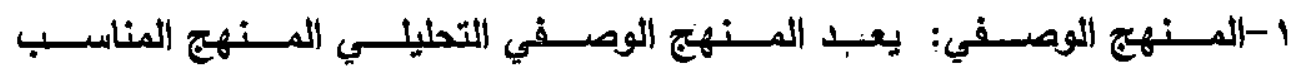

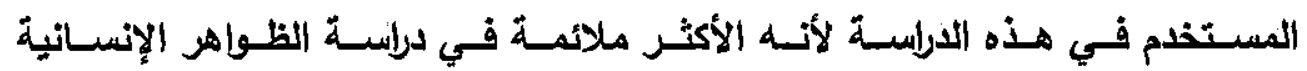

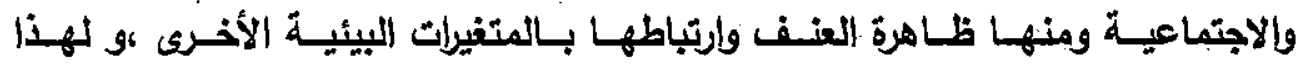




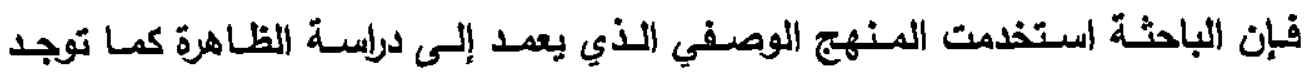

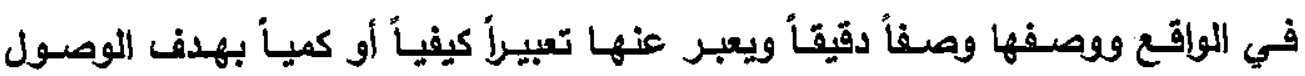

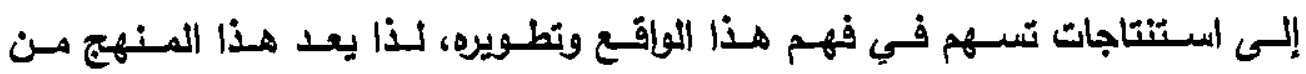

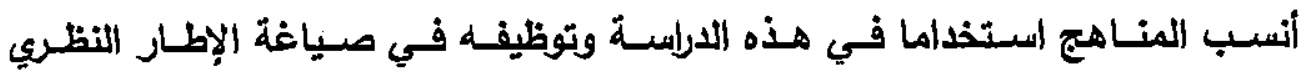

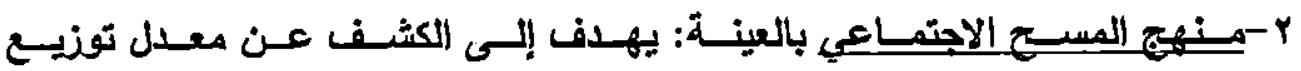
بعـض الخصسائص الاجتمابيـة كـالنوع- محسل الإقامسة - التخصسص -- المقتنبـات التكنولوجيـة الشخصـية )ويحــد كيـف تــتبط هـذه الخصـائص بأنمــاط سـلوكية

ثامنا: أداة جميع اللبيانات

تعـد أدوات جمــع البيانـات مـن الوبــائل التــي مـن خلالهـا يمكن للباحـث

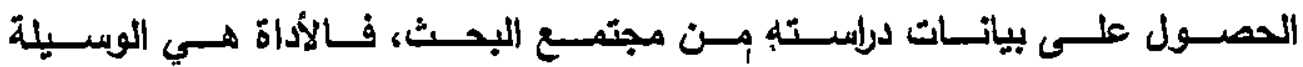

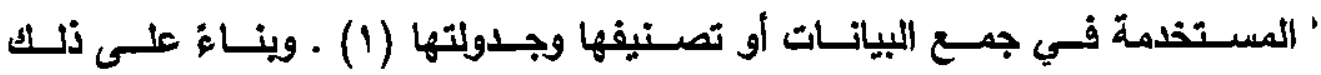

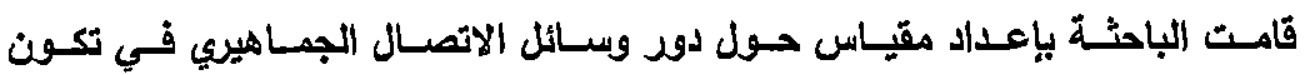

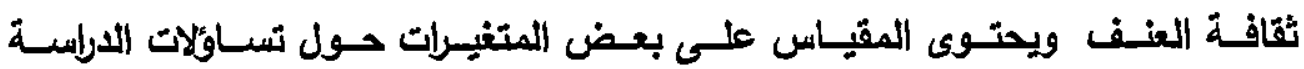
ألتي أوضحتها الباحثة بسابقاً.

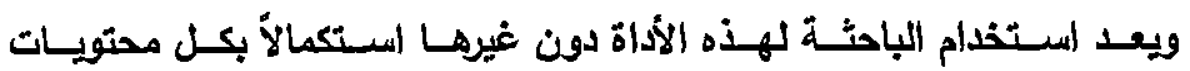

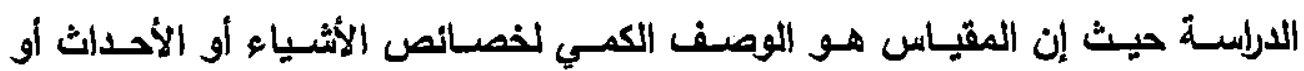

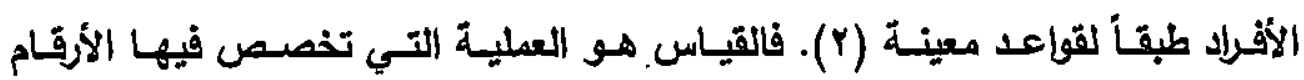
لسمات أو خصائص أو مواضيع أو أحداث تبعاً لصوغ قواعد محدة (r) . 


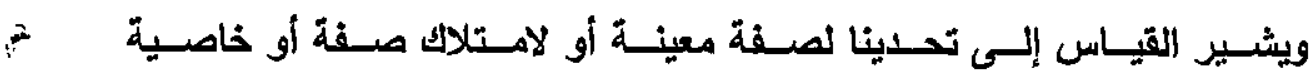

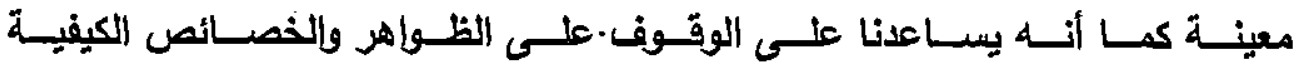

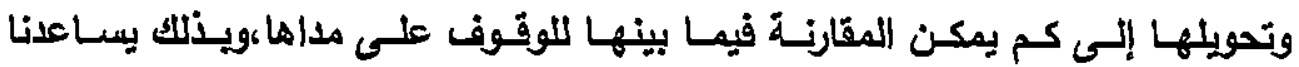
القيـاس علـى أن نكثـف مـدى ومقـدار الخـواص الكيفيـة ويـلـخل ضسمن القيـاس العـلد وإلترتيـب تصــاعديا أو تنازليـا لخـواص أو صـفات معينــة نفهـم فـي ضـونها حالة الأفراد ونضعهم في مستويات معينة .(؟) وصف المقيليس

يتكون المقياس الحالمي من المحاور الأساسية التالية :

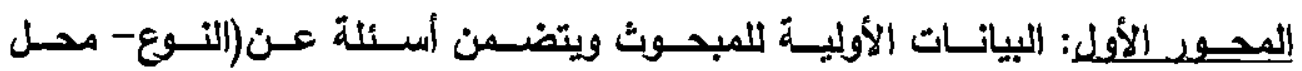
الإقامة - الكلية مالمقتنيات الشخصية التكنولوجية).

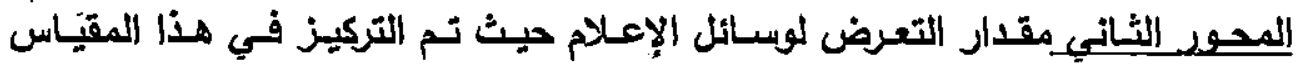

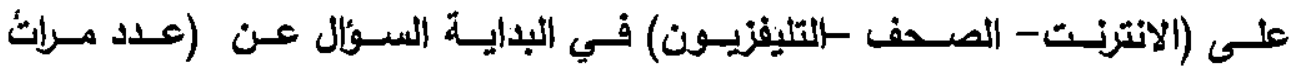

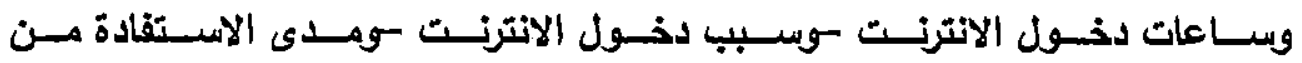

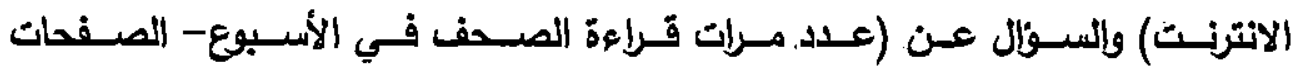

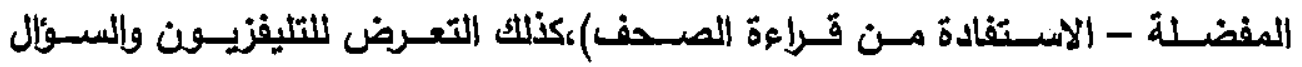

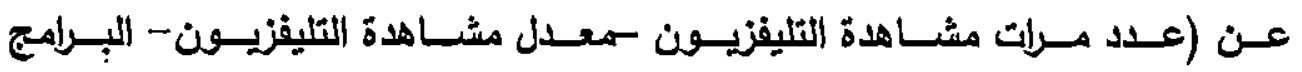
المفضـلة كمـدى الأسستقادة مـن مشـاهدة التلافزيـون ) تـم صسياغة مجموعـة مـن العبارات عن الوبسائل الثُلاث . 
الأتصال الجماهيري والعنف روية سوسيولوجية

هبه شريف صديق

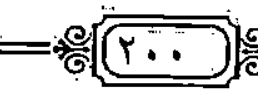

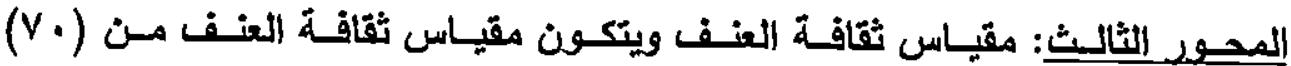
عبـارة لقيـاس ثلاثـة محساور هـي : (مفـاهيم وتصـورلت حـول العنـفــ المعلومـات وإلمعارف حول العنف-ممارسات العنف في الحياة) تاسعاً: تحليل و تفسير اللبيانات

يتـداخل التفسير مـع التحليـل مـن خـلال وضــع البيانـات والنتـاتج الميدانيـة فـي إطارهـا العـام لتوضـيح الـدلالات الاجتماعيـة لهـذه البيانـات ، كمـا اسـتخدمت

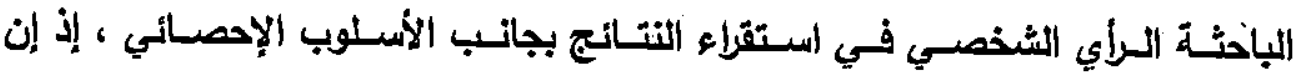

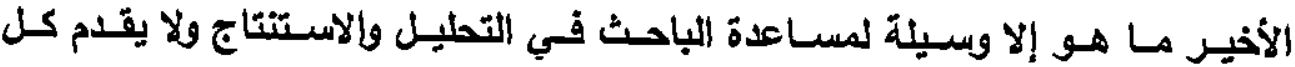

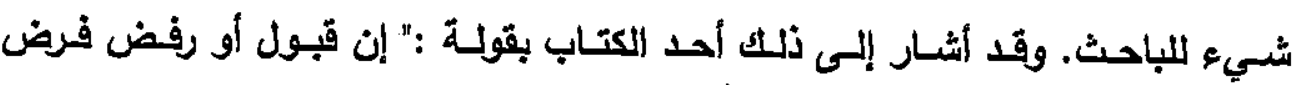

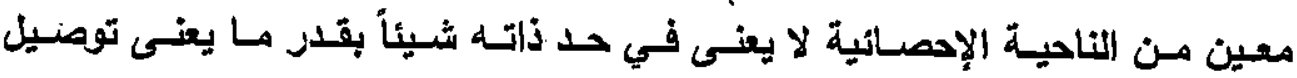

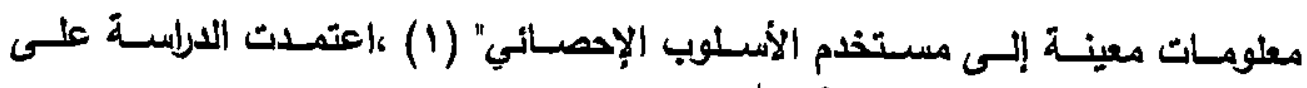
الاتطيل الكمي والكيفي معاً.

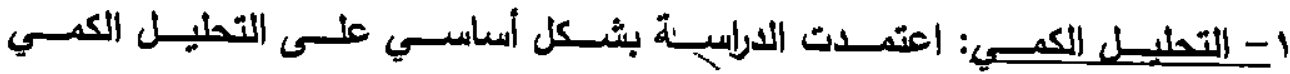
للبيانـات البكميـة الناتجـة عن التحليـل الاحصنانى للمقيساس الـــي طبق على عينـة

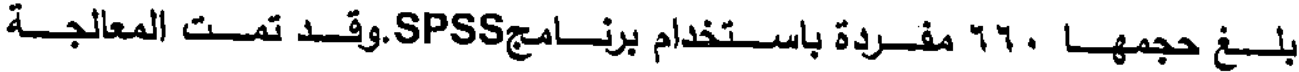

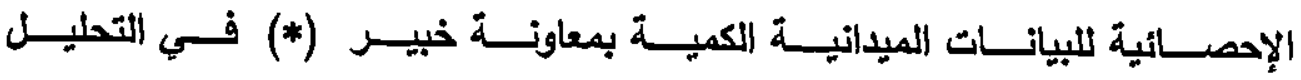
الاحصائى، اشتملت خطة التحليل الاحصائى للبيانات على التحيلات التالية: (Alpha Cronbach internal حساب الثبات باستخدام معادلة ألفا كرونباخ وكذلك اسنخدام أسلوبب التجزئة النصفية (Splet-helf). 
r. معامل ارتباط بيريون Pearson Correlation Coefficient لحسياب ثبات

إعادة التطبيث وصدق الاتساق الداخلي وحساب درجة الاربتباط.

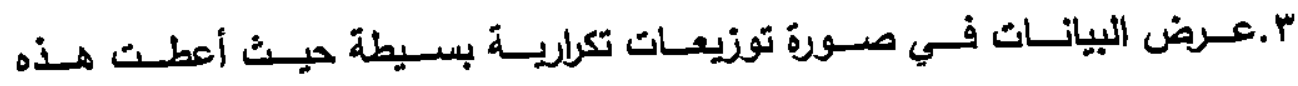

التوزيعات صورة عامة لتوزيع خصائص عينة الاراسة والمتغيرات المدروبة.

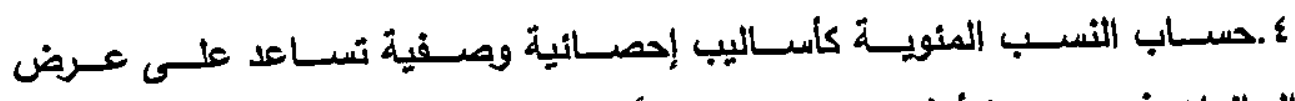

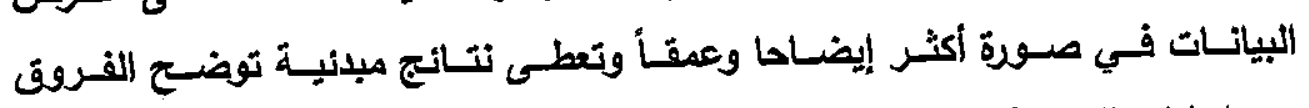
بين إجابات المبحوثين.

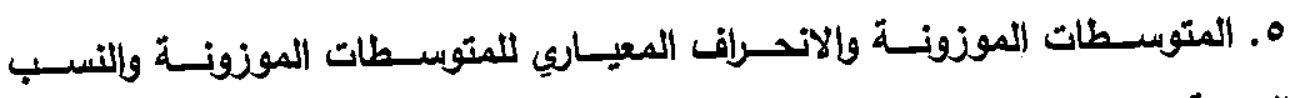
المئوية للمتوبسطات الموزونة.

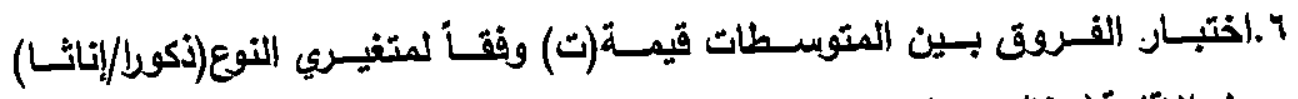
ومحل الإقامةُ(ريفا/حضرا). V.تحيل التباين الثنائي ANOVA اللتعرف على القرق والتأثير.

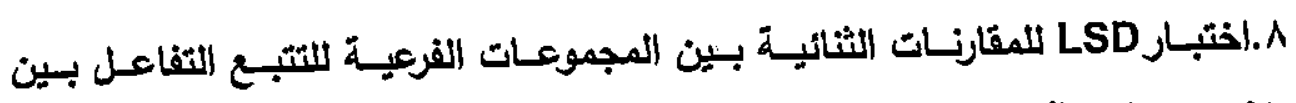

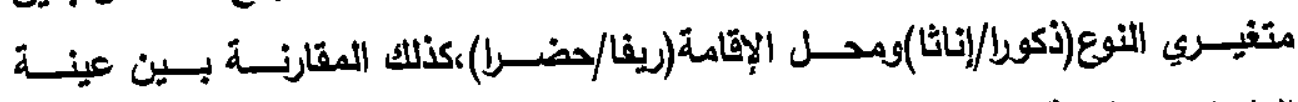

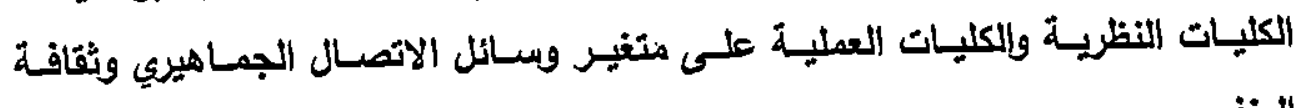
المنف .

9 . تحليل الاتحدلر متعدد المتغيرات المنبئة(Regression Analysis) بطريقة الخطوات المتدرجة Stepwise للتعرف على مدى إمكاتية التنبو بثقافة العنف .

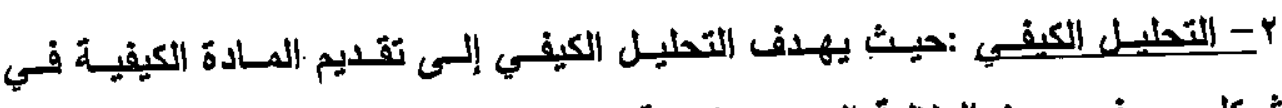

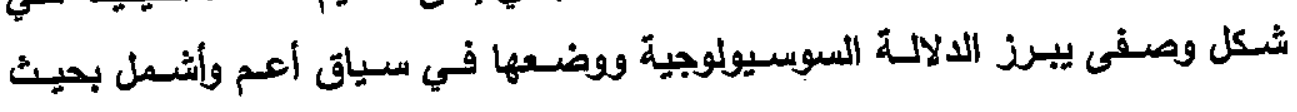


تكتسبـ دلالاتهـا الاجتماعيـة، ولتحقيـق هـذا الهـدف سـيتم تفسـير البياتـات فـي

ضوء النظرية للبحث وإستخدامها في تفسير البيانات (1).

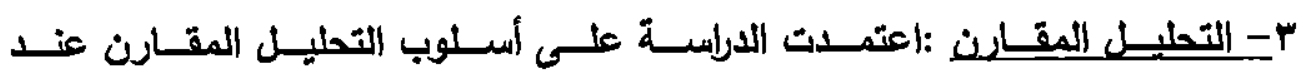

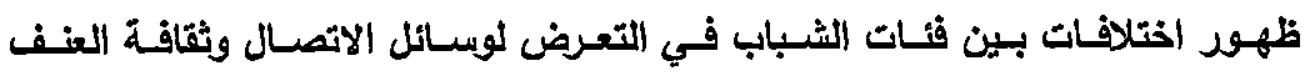
مـع الأخـذفي الاعتبـار المـزج بينهما في عمليـة التحليل وذلك للتوصل إلـى نتائج أكثر دلالة.

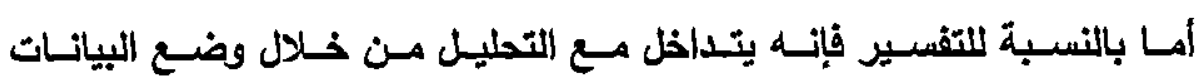

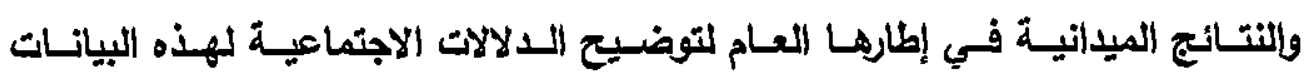
كلا اعتمدت الباحثةّة على نوعين من التقسير:

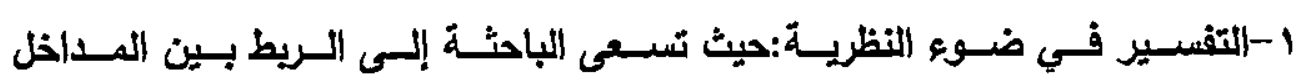
والمنطلقات النظرية واستخدامها في تفسير المتائج الميدانية. Y-التقسير فـي ضـوء نتـاتج الدراسـات السـابقة: حيـث تسـعى الباحثة إلـى المريط بين نتائج الدراسات السابقة ونتائج الدرإة الرارهة.

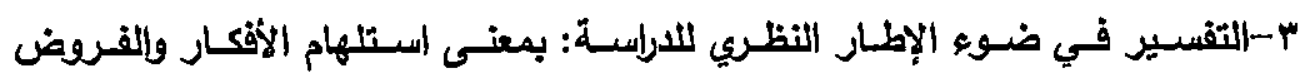

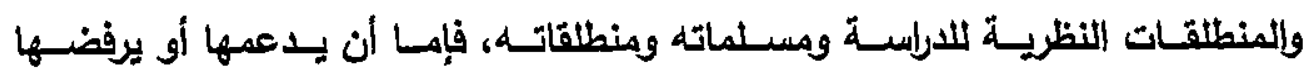
أو يجرى تثقيحها وتعديلها.

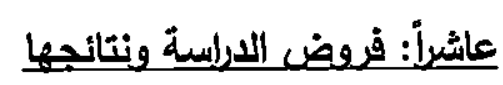

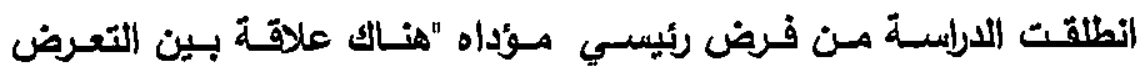

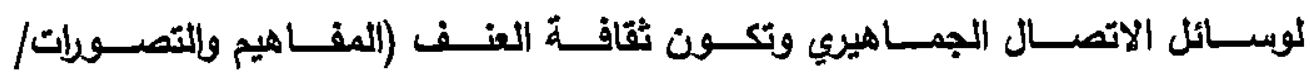

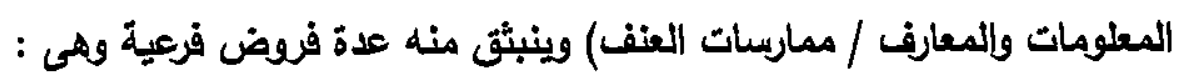




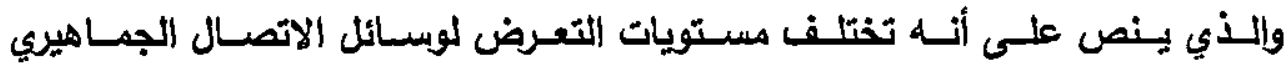

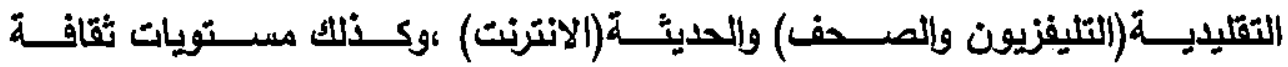

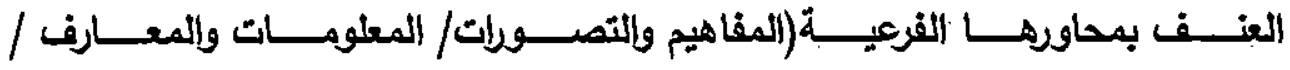
ممارسات العنف) لدى عينة الدراسة من الثنباب الجامعي. - كثــفت نتــائج الدراســة أن مســتوى التعـرض لوســائل الاتصــال الجمـاهيري

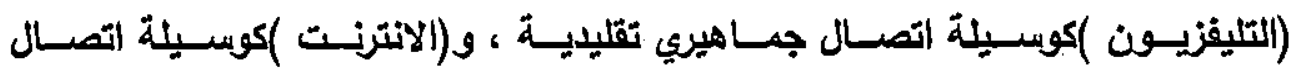

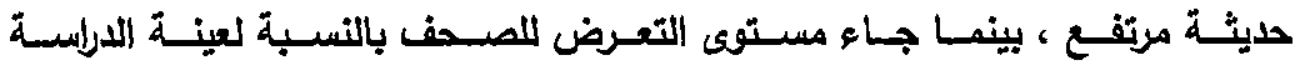

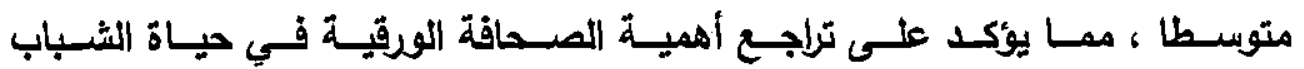

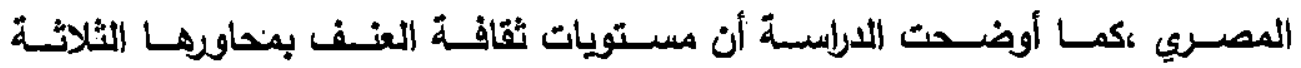

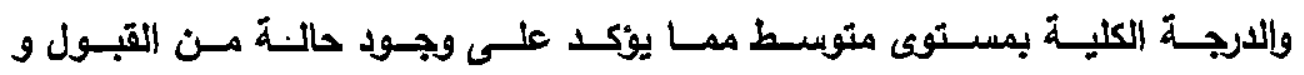
الأستحسان الثقافي للعنف للى الثباب الجامعي عينة اللدراسة .

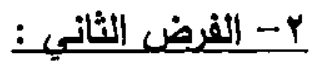

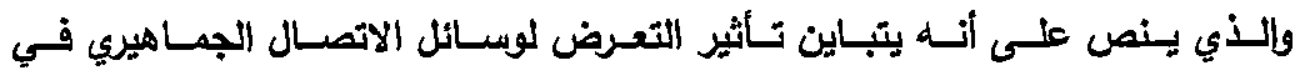
تشـكيل ثقافـة العنـف لـدى الثـباب الجـامعي بتبـاين متغيـري النـوع (ذكور)/إناثـا) ، محل الإقامة (ريفا/حضرل) ،والتقاعل بينهم؟ - بالنسبة لتأثير متغير النوع

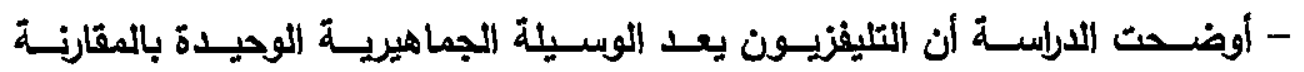
بالصـحف والانترنـت فـي إحـداث فـروق بـين الـذكور والإنـاث حيست تبـين وجـود 
الأتصال الجماهيري والعنف روية سوسيولوجية

هبه شريف صديق

$=$ Y.

فروق ذات دلادة إحصـائية دالـة بـين عينـة الـكور والإنـاث في التعرض لمشـاهدة التليفزيون وذلك لصالح عينة الإناث.

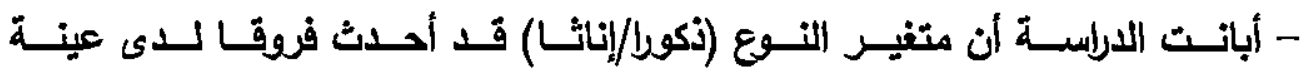

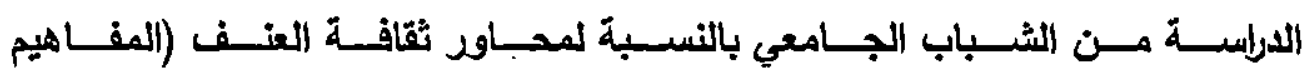

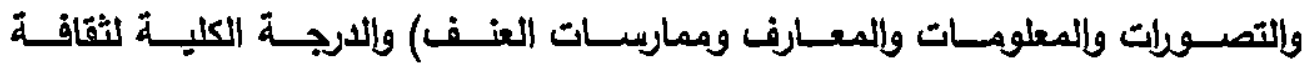

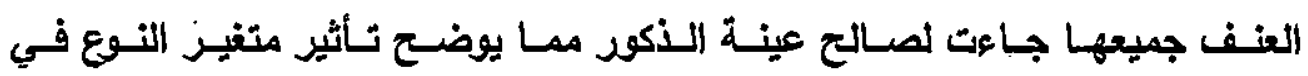

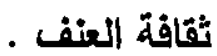

بالنسبة تقأثبر متنغير محل الإقامة -كثـفت نتائج الارلسـة وجـود فروق ذات دلالـة إحصـائية دالـة بـين عينـة (الريـف

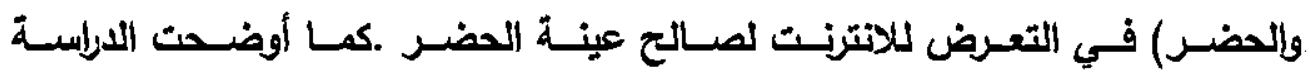
أيضـا وجـود فـروق ذات دلالـة إحصـائية دالـة بـين عينـة ( الريـف والحضـر ) في التعرض للصحف لصالح عينة الريف . - أسـفربت نتـائج الإلســة عـن عـدم وجـود فـروق دالـة إحصـائيا بـين الثـباب

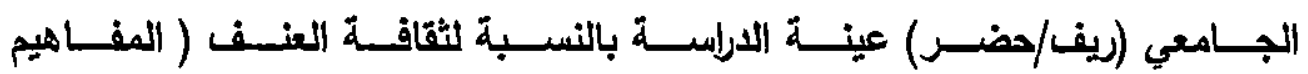

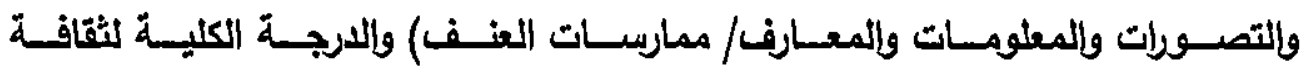


الأتصال الجماهيري والعنف روية سوسيؤوجية

هبه شريف صديق

$=$ Y.0.

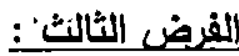

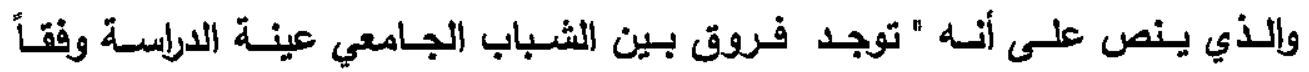

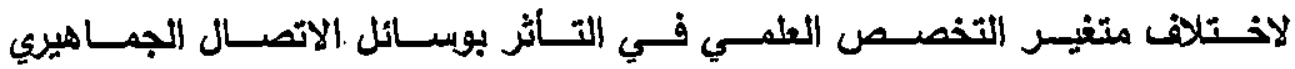

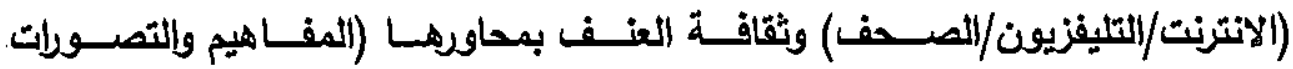
والمغلومسـات والمعـارف وممارسـات العنــف) لـدى عينــة الاراســة مـن الثــباب |ل الجامعي".

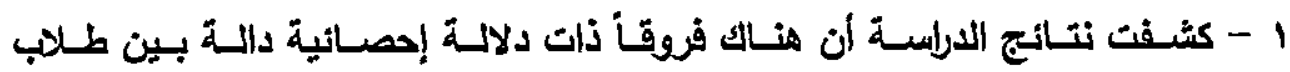
الكليـات النظريـة والعمليـة في التعـرض للانترنت فكانت الفـروف في اتجـاه الكليـات العماية. r - أشـارت نتـائج الارلبـة إلـى وجـود فـوق ذات دلالـة إحصـائية بـين عينتى

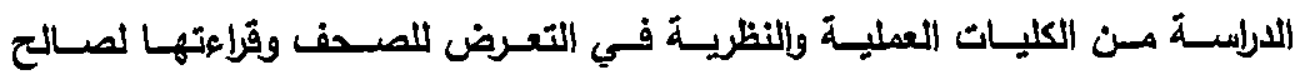
الكليات النظرية ، أما التعرض لمشاهدة التليفزيون لم يكن دال إحصائيا. r - ويالنسـبة لمحساور ثقافـة العنـف فقـد أبانـت نتـائج الاراسـة وجـود فـروق ذات

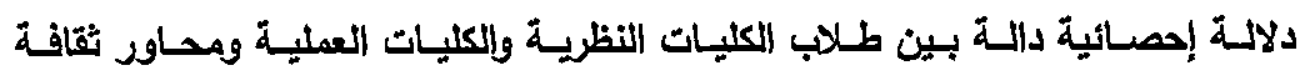

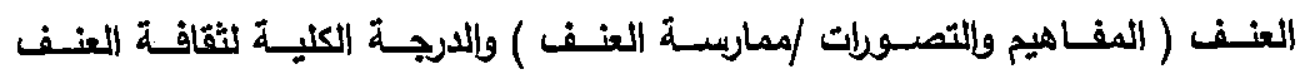
لصالح الكليات النظرية .

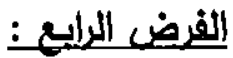

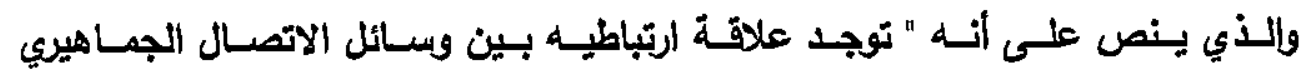

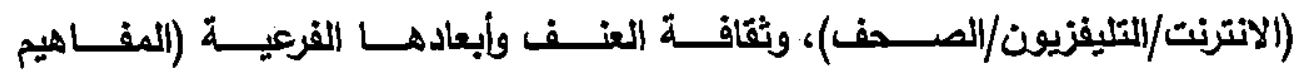


والمتصـورات والمعلومـات وإلمعـارف وممارسـات العنـف لـدى عينـة الاراســة مسن الثباب الجامعي

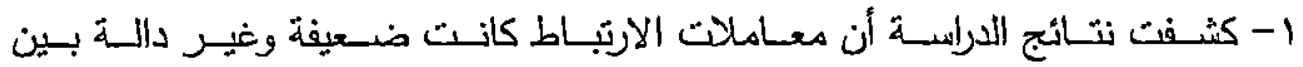

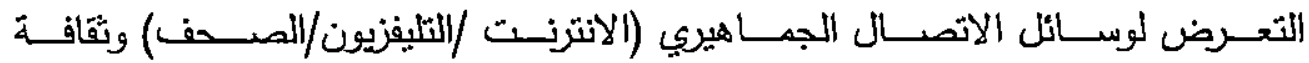

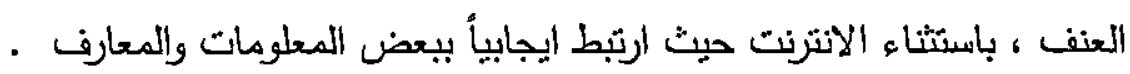
الفرض الخامسن:

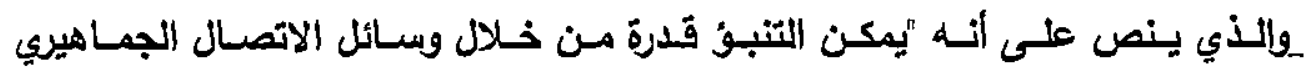

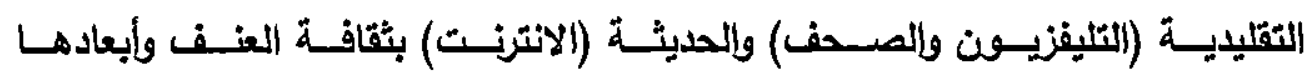

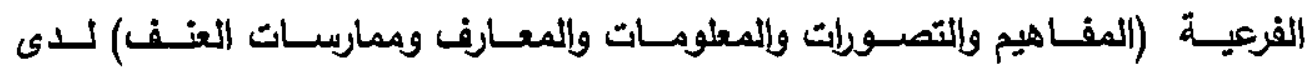
عينة الاراسة من الشباب الجامعي.

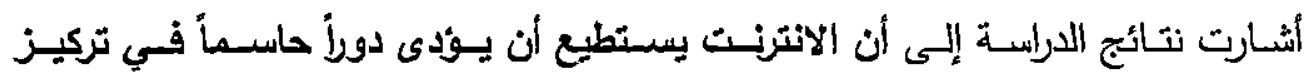

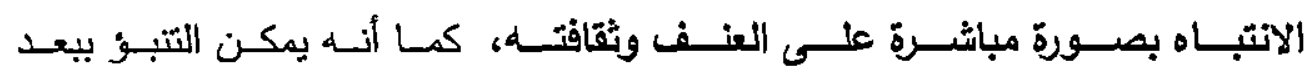

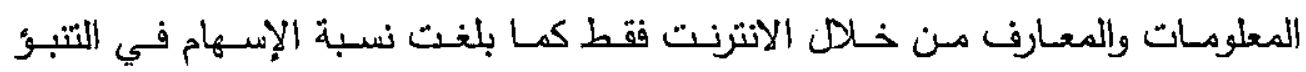
بدرجة المعلومات والمعارف من خلال درجة التعرض للانترنت r.1\%. 
الأتصال الجماهيري والعنف روية سوسيولوجية

هبه شُريف صديق

$=r . V$ r

الحواثشي السفلية

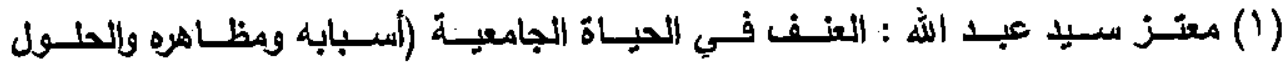

المقترحة لمعالجته) ـ القاهزة ، مركز البحوث واللدراسات النفسية ه . . بم . ص ع .

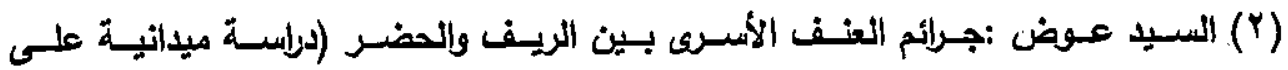

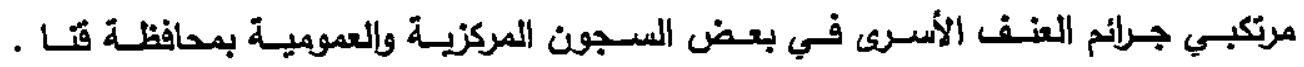

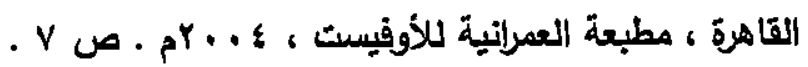

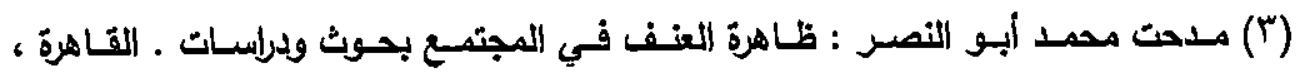

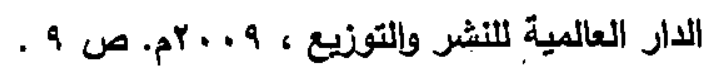

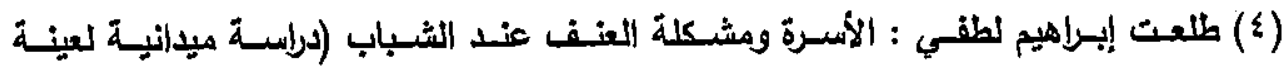

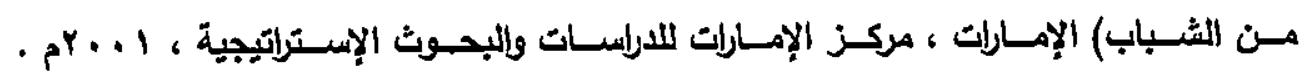
-

(0) محمـود أحمـد حمـاد : المعالجـة التليفزيونيـة لأحساث العنـف فـي مصـر (دراســة ميإنية لاتجاهات طلاب الجامعات المصرية) . .9.9 19.ص V. (T) الســيد عـوض : التطــور التكنولـوجي والجريمــة.أعمال المــؤتمر الســنوي الرايــع

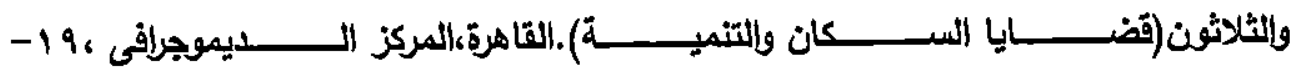

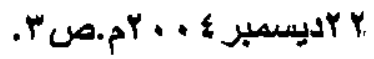


الأتصال الجماهيري والعنف روية سوسيولوجية

هبه شريف صديق

$=\gamma \cdot 1$

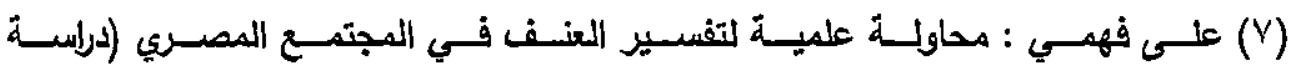

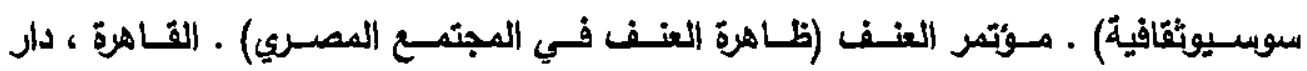

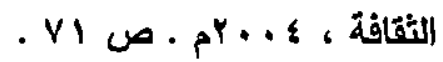

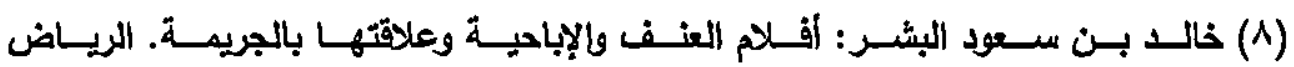

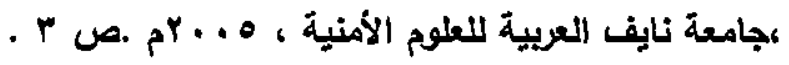

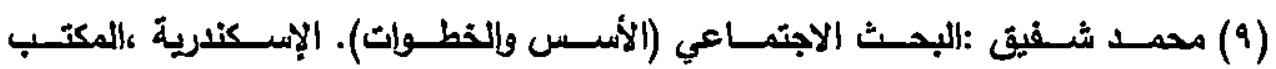

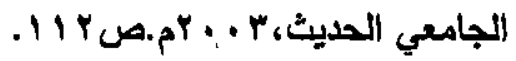

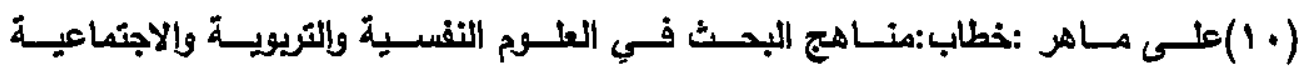

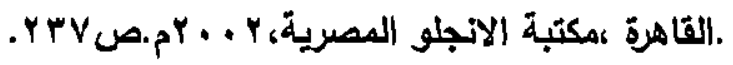

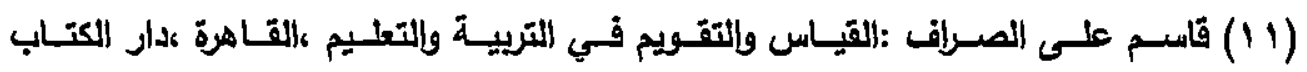

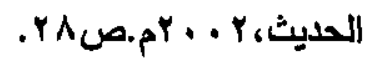

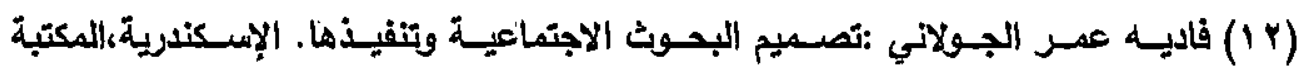

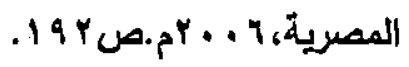

(13) D.R. plane \& E.B. Oppermann, statistics for Management Decisions, Texas, business publications Inc , 1997.p.205 .

(1 إ) عاون الباحثة في المعالجة الإحصائية للبيانات المبياتية دأحمد كمال البهنساوى مدرس علم النفس بكلية الآداب -جامعة أسيوط (10) أحم زليد :تصميم البحث الاجتماعي(أسس منهجية وتطبيقات عملية ).

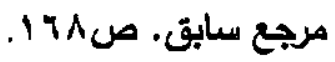

